\title{
Anopheles gambiae complex along The Gambia river, with particular reference to the molecular forms of An. gambiae s.s Beniamino Caputo $^{\dagger 1}$, Davis Nwakanma ${ }^{\dagger 2}$, Musa Jawara ${ }^{\dagger 2}$, Majidah Adiamoh ${ }^{2}$, Ibrahima Dia ${ }^{3}$, Lassana Konate ${ }^{4}$, Vincenzo Petrarca ${ }^{5}$, David J Conway*2 and Alessandra della Torre*1
}

\begin{abstract}
Address: ${ }^{1}$ Istituto Pasteur-Fondazione Cenci-Bolognetti, Sezione di Parassitologia, Dipartimento di Scienze di Sanità Pubblica, Università "La Sapienza", Piazzale Aldo Moro 5, 00185, Rome, Italy, ${ }^{2}$ Medical Research Council Laboratories, Fajara, P.O. Box 273, Banjul, The Gambia, ${ }^{3}$ Institut Pasteur, Dakar, Senegal, ${ }^{4}$ University of Dakar, Senegal and ${ }^{5}$ Istituto Pasteur-Fondazione Cenci-Bolognetti, Dipartimento di Genetica e Biologia Molecolare, Università "La Sapienza", Rome, Italy

Email: Beniamino Caputo - beniamino.caputo@uniroma1.it; Davis Nwakanma - dnwakanma@mrc.gm; Musa Jawara - mjawara@mrc.gm; Majidah Adiamoh - madiamoh@mrc.gm; Ibrahima Dia - dia@pasteur.sn; Lassana Konate - konatela@yahoo.fr;

Vincenzo Petrarca - vincenzo.petrarca@uniroma1.it; David J Conway* - dconway@mrc.gm; Alessandra della

Torre* - ale.dellatorre@uniroma1.it

* Corresponding authors †Equal contributors
\end{abstract}

Published: 22 September 2008

Malaria Journal 2008, 7:182 doi:10.1186/1475-2875-7-182
Received: 10 June 2008

Accepted: 22 September 2008

This article is available from: http://www.malariajournal.com/content/7/I//82

(c) 2008 Caputo et al; licensee BioMed Central Ltd.

This is an Open Access article distributed under the terms of the Creative Commons Attribution License (http://creativecommons.org/licenses/by/2.0), which permits unrestricted use, distribution, and reproduction in any medium, provided the original work is properly cited.

\begin{abstract}
Background: The geographic and temporal distribution of $\mathrm{M}$ and $\mathrm{S}$ molecular forms of the major Afrotropical malaria vector species Anopheles gambiae s.s. at the western extreme of their range of distribution has never been investigated in detail.

Materials and methods: Collections of indoor-resting An. gambiae s.l. females were carried out along a ca. $400 \mathrm{~km}$ west to east transect following the River Gambia from the western coastal region of The Gambia to south-eastern Senegal during 2005 end of rainy season/early dry season and the 2006 rainy season. Specimens were identified to species and molecular forms by PCR-RFLP and the origin of blood-meal of fed females was determined by ELISA test.

Results: Over 4,000 An. gambiae s.l. adult females were collected and identified, I,04I and 3,038 in 2005 and 2006, respectively. M-form was mainly found in sympatry with Anopheles melas and Sform in the western part of the transect, and with Anopheles arabiensis in the central part. S-form was found to prevail in rural Sudan-Guinean savannah areas of Eastern Senegal, in sympatry with An. arabiensis. Anopheles melas and An. arabiensis relative frequencies were generally lower in the rainy season samples, when An. gambiae s.s. was prevailing. No large seasonal fluctuations were observed for $\mathrm{M}$ and $\mathrm{S}$-forms. In areas where both $\mathrm{M}$ and $\mathrm{S}$ were recorded, the frequency of hybrids between them ranged from to $0.6 \%$ to $7 \%$.

Discussion: The observed pattern of taxa distribution supports the hypothesis of a better adaptation of M-form to areas characterized by water-retaining alluvial deposits along the Gambia River, characterized by marshy vegetation, mangrove woods and rice cultivations. In contrast, the S-form seems to be better adapted to free-draining soil, covered with open woodland savannah or farmland, rich in temporary larval breeding sites characterizing mainly the eastern part of the transect, where the environmental impact of the Gambia River is much less profound and
\end{abstract}


agricultural activities are mainly rain-dependent. Very interestingly, the observed frequency of hybridization between the molecular forms along the whole transect was much higher than has been reported so far for other areas.

Conclusion: The results support a bionomic divergence between the $M$ and $S$-forms, and suggest that the western extreme of An. gambiae s.s. geographical distribution may represent an area of higher-than-expected hybridization between the two molecular forms.

\section{Background}

The River Gambia is one of the major rivers in West Africa, running for more than 1,100 km from the Fouta Djalon plateau (northern Guinea), flowing north-west into the Tambacounda province of Senegal, and then westward to the Atlantic Ocean at the city of Banjul in The Gambia. The river greatly affects the ecology of the neighbouring areas and provides many breeding opportunities for anopheline malaria vectors.

The most detailed surveys on the presence and prevalence in this region of the malaria vector species belonging to the Anopheles gambiae complex date back to more than 25 years ago, when Bryan and collaborators analysed the distribution of the three sympatric members of the complex (i.e. the fresh water species Anopheles gambiae s.s. and Anopheles arabiensis and the salt water species Anopheles melas) in The Gambia and surrounding Senegalese areas $[1,2]$. These studies showed that during the rainy season An. gambiae s.s. was widely distributed throughout the region, while An. melas reached up to more than $150 \mathrm{~km}$ inland and increased its frequency at the beginning of the rainy season (July) or early dry season (Nov-Dec), when the brackish environments become more common. A more recent study confirmed these previous observations, showing also that An. melas is subject to large fluctuations in its densities, due to competition with the fresh water An. gambiae s.s. larvae in breeding sites characterized by salt concentration below 30\% sea water [3]. The fresh water species An. arabiensis was recorded mainly in the eastern, inland part of The Gambia and in the northern, neighbouring Senegalese region of Saloum [1,4]. Bogh et al [3] suggested that the main breeding habitat for An. arabiensis in the area was in rain-fed rice fields along the edge of the alluvial soils. Lindsay et al [5] found that An. arabiensis was the dominant vector species during the dry season when rice fields in the middle river zone were irrigated.

The above-cited studies, however, did not take into consideration the recent splitting of the major vector species, An. gambiae s.s., into the M- and S-molecular forms, based on identification of form-specific haplotypes in the rDNA region [6]. These two molecular forms are known to be largely sympatric in the whole Afro-tropical region west of the Great Rift Valley, and to be characterized by a high degree of reproductive isolation [7] and by restricted genomic areas of genetic differentiation ("speciation islands" sensu Turner, [8]), suggesting that the two forms are undergoing a speciation process. From the ecological point of view the S-form seems to be mostly associated with small rain-dependent breeding sites, while the $\mathrm{M}$ form seems more associated with semi-permanent breeding sites, frequently created by human activities, such as rice cultivations [9-13]. From the epidemiological point of view, although preliminary observations do not clearly support any difference in the ability of the two forms as malaria vectors $[14,15]$, their different larval ecology may affect their temporal and spatial dynamics and, consequently, malaria transmission in some regions, as suggested by Touré and collaborators $[16,17]$. Moreover, the different spread of insecticide resistance mechanisms in the two forms, such as the knock-down resistance $(k d r)$ [18], should be taken into consideration when planning insecticide-based control activities against these vectors. So far, the only information available on An. gambiae molecular forms along the Gambia River refer to small samples from The Gambia [7] and Eastern Senegal [18].

This article presents the results of adult An. gambiae s.l. collections along a $400 \mathrm{~km}$ west to east transect from the western coastal region of The Gambia (Kartung, $16^{\circ} 45^{\prime} \mathrm{W}$ ) to south-eastern Senegal (Kedougou, $\left.12^{\circ} 07^{\prime} \mathrm{W}\right)$, during the 2005 end of rainy season/early dry season and the 2006 rainy season, to study the geographic and temporal distribution of the two molecular forms of An. gambiae s.s. and of the other taxa of the An. gambiae complex sympatric in the area. The results highlight evidence of strong bionomic divergence between the $M$ and S-forms and, unexpectedly, reveal that at the extreme west of their range of distribution they show a level of hybridization higher than that reported from other west African geographical areas.

\section{Materials and methods} Study area and sampling sites

A west to east transect about $400 \mathrm{~km}$ long was conducted along the Gambia River from the western coastal region of The Gambia $\left(16^{\circ} 45^{\prime} \mathrm{W}\right)$ to south-eastern Senegal $\left(12^{\circ} 07^{\prime} \mathrm{W}\right)$, during the end of rainy season/early dry season 2005 (from 12 October to 20 November, hereafter conventionally referred as ERS-2005, because 2005 rainy 
season was unusually short, see Additional file 1) and the 2006 rainy season (from 8 August to 14 October, hereafter referred as RS-2006).

The western part of the sampled transect extends through the country of The Gambia and largely consists of flat woodland savannas and riverine swamps. The river is extremely flat, and therefore subject to salt water intrusion, moving up and down the river during the course of the year; the flow is highly seasonal and rain-dependent. The "salt-front" is at its highest (about $180 \mathrm{~km}$ inland) in the late dry season (June) and at its lowest at the end of the rainy season (October). The area lies within the tropical sub-humid eco-climatic zone (Guinean-Sudanese) and is characterized by a wet season (generally between late June and early November) and a 7-8 month dry season. Gambian annual rainfall ranges between 1,200 mm in south-western regions and $800 \mathrm{~mm}$ in the north-eastern areas, showing large spatial and temporal variations. The soil structure of The Gambia can be broken down into two main groups: the Pleistocene-Recent river alluvium deposited by the Gambia River and its drainage network with mangrove forests, marsh vegetation or rice cultivations, and the Tertiary ferruginous sandstone soils, with open woodland savannahs or farmland [19]. The easternmost part of the transect lies in south-eastern Senegal (from $13^{\circ} 40^{\prime}$ to $12^{\circ} 07^{\prime} \mathrm{W}$ ) and extends up to the slopes of Futa Djalon highlands. It lies in the Southern-Sudanese and Sudanese-Guinean savanna eco-climatic belt and is characterized by a tropical, hot and humid climate, with precipitations from June to November and large variations in the mean annual rainfall (from 1,300 to 1,800 $\mathrm{mm}$ in Kedougou area).

Mosquitoes were collected in 35 sampling sites (Figure 1 and Table 1): 17 in ERS-2005 and 28 (including 10 of the 17 villages already sampled in 2005) in RS-2006, within four main arbitrarily defined areas. The main ecological characteristics of the sampling sites are described below, based on literature data $[20,21]$, personal observations and, in the case of sites in The Gambia only, utilizing a "landscape approach" using Geographic Information System (GIS) technology (ArcMap GIS Version 9.2; ESRI). This latter approach was based on The Gambia GIS database (2002), with a resolution of $40 \mathrm{~m}$ grid intersection based on UTM28 coordinate system. A $1-\mathrm{km}$ radius area was generated around each sampling site, using a GIS process known as buffering [22,23]; polygonal buffers based on different Landscape Elements were overlain on the landscape map and the relative proportion of each of them in the area was calculated. Seven main landscape elements were considered: Ricefield, Cultivation (any vegetable, excluding rice), Woods, Mangrove, Grassland/Low Growth, Swamp, Populated Areas (data shown in Additional file 2).

\section{Lower river area (LRA)}

This area extends about $180 \mathrm{~km}$ inland from the mouth of the river and is characterized by extensive tidal flooding. The land bordering the river largely consists of low-lying alluvial terraces subject to salt water intrusion, which make them generally unsuitable for cultivation. Agriculture is possible $110 \mathrm{~km}$ upstream of the coast, mainly in the rainy season, depending on the extent to which rainfall and river flooding are able to wash salt from the fields. A more detailed description of the sampling sites is provided by further sub-dividing this area into three subareas, as follows.

With a population of 392,000 (29\% of the total population of The Gambia), the western sub-area (LRA-W) is the most populous local government area. Relatively mild temperatures and higher rainfall makes LRA-W particularly suitable for cropping. Increased urbanization in the area has resulted in the lost of large areas of home gardens, tree orchards and farmlands. Collections were carried out in three sites: 1) Mandina $\mathrm{Ba}$, closer to the mouth of the Gambia River and mainly characterized by cultivation and mangrove landscapes; 2) Kartong, located in the south part of coastal area in front of the ocean and mainly characterized by ricefield landscape; 3) Jiborah, located $12 \mathrm{~km}$ south of the river, mainly characterized by raindependent cultivation.

The South Bank sub-area (LRA-S), with a population of 72,500 , is the least populated area in the Gambia. The LRA-S is a primarily agricultural area with most people engaged in the production of groundnuts, millet and rice and has a large cattle population. Collections were carried out in three sites: 1-2) Kemoto and Tankular, located at a distance of about $10 \mathrm{~km}$ from each other near flooded swamps bordering the river, and mainly characterized by mangrove and ricefield landscapes, respectively; 3) Keneba, a large village about $2 \mathrm{~km}$ away from mangrove swamps associated with the Bintang Bolong tributary, and mainly characterized by cultivation and grassland landscapes.

The North Bank sub-area (LRA-N) is characterized by brackish and fresh water environments in close proximity of more arid Sudan Savanna areas. Collections were carried out in three different zones in a $40 \mathrm{~km}$ range from Farafenni westwards in RS-2006 and in Farafenni zone only in ERS-2005: 1) three sites in Njabakunda zone (Sara Samba Sowe and Sare Ilo Buya, less than $1 \mathrm{~km}$ apart from each other, and Hamdalai, westwards), located more than $4 \mathrm{~km}$ from the river on free-draining sand laterite, covered with open woodland savannah or farmland and mainly characterized by cultivation landscape; 2) three sites in Yallal zone, Dai Mandinka and Jajari, less than $1 \mathrm{~km}$ from the Bao Bolong, a tributary of the Gambia River with 
Table I: Collection sites of Anopheles gambiae sensu lato in the west to east transect from coastal The Gambia to eastern Senegal.

\begin{tabular}{|c|c|c|c|c|c|}
\hline Site code & Village & Method & Lat. N & Long. E & Date \\
\hline & Lower River Area, Western (LRA-W) & & & & \\
\hline 1 & Kartong & IR_PSC & $13^{\circ} 05^{\prime}$ & $16^{\circ} 45^{\prime}$ & $2-3 / 10 / 06$ \\
\hline 2 & Mandinaba & IR_PSC & $13^{\circ} 17^{\prime}$ & $16^{\circ} 35^{\prime}$ & $9-10 / 11 / 2005 \& 20 / 11 / 05$ \\
\hline 2 & Mandinaba & IR_PSC & $13^{\circ} 17^{\prime}$ & $16^{\circ} 35^{\prime}$ & $28 / 09 / 05$ to $2 / 10 / 06$ \\
\hline \multirow[t]{2}{*}{3} & Jiboro Kuta & IR_PSC & $13^{\circ} \mathrm{II}$ & $16^{\circ} 34$ & $27 / 9 / 06$ \\
\hline & Lower River Area, South Bank (LRA-S) & & & & \\
\hline 4 & Kemoto & IR_PSC \& IR_HC & $13^{\circ} 26^{\prime}$ & $16^{\circ} 09^{\prime}$ & $|3-14 /| 1 / 05$ \\
\hline 5 & Tankular & IR_PSC $^{-}$ & $13^{\circ} 25^{\prime}$ & $16^{\circ} 02^{\prime}$ & $13-14-15 / 11 / 05$ \\
\hline 5 & Tankular & IR_PSC & $13^{\circ} 25^{\prime}$ & $16^{\circ} 02^{\prime}$ & $17-18 / 08 / 06$ \\
\hline 6 & Keneba & IR_HC & $13^{\circ} 20^{\prime}$ & $16^{\circ} 01^{\prime}$ & $12 / 10 / 05$ \\
\hline \multirow{2}{*}{6} & Keneba & IR_PSC & $13^{\circ} 20^{\prime}$ & $16^{\circ} 01^{\prime}$ & $19 / 08 / 06$ \\
\hline & Lower River Area, North Bank (LRA-N) & & & & \\
\hline 7 & Hamdalai & IR_PSC & $13^{\circ} 34^{\prime}$ & $16^{\circ} \mathrm{I}^{\prime}$ & $25 / 9 / 06$ \\
\hline $8 \mathrm{a}$ & Sare Samba Sowe & IR_PSC & $13^{\circ} 35^{\prime}$ & $15^{\circ} 54^{\prime}$ & $12-15 / 8 / 06$ \\
\hline $8 b$ & Sare Samba Sowe & IR_PSC & $13^{\circ} 35^{\prime}$ & $15^{\circ} 54^{\prime}$ & $19-20 / 9 / 06$ \\
\hline 8 & Sare Samba Sowe 2006 & IR_PSC & $13^{\circ} 35^{\prime}$ & $15^{\circ} 54^{\prime}$ & 2006 \\
\hline 9 & Sare Illo Buya & IR_PSC & $13^{\circ} 35^{\prime}$ & $15^{\circ} 52^{\prime}$ & 14/8/06 \\
\hline 10 & Dai Mandinka & IR_PSC & $13^{\circ} 33^{\prime}$ & $15^{\circ} 49^{\prime}$ & $14 / 10 / 2006$ \\
\hline 11 & Jajari & IR_PSC & $\mathrm{n} / \mathrm{a}$ & $\mathrm{n} / \mathrm{a}$ & $13 / 10 / 2006$ \\
\hline 12 & Yallal & IR_PSC & $13^{\circ} 33^{\prime}$ & $15^{\circ} 42^{\prime}$ & $12-15 / 10 / 2006$ \\
\hline 13 & Ker Madi & IR_HC & $13^{\circ} 32^{\prime}$ & $15^{\circ} 37^{\prime}$ & $13-14 / 10 / 05$ \\
\hline 13 & Ker Madi & AS_HC & $13^{\circ} 32^{\prime}$ & $15^{\circ} 37^{\prime}$ & $14 / 10 / 05$ \\
\hline 13 & Ker Madi & IR_PSC & $13^{\circ} 32^{\prime}$ & $15^{\circ} 37^{\prime}$ & $11-13 / 08 / 06$ \\
\hline 14 & Kalataba & IR_PSC & $13^{\circ} 33^{\prime}$ & $15^{\circ} 37^{\prime}$ & $13 / 08 / 06$ \\
\hline 15 & Ballingho & IR_HC & $13^{\circ} 30^{\prime}$ & $15^{\circ} 36^{\prime}$ & $13 / 10 / 05$ \\
\hline \multirow[t]{2}{*}{15} & Ballingho & AS_HC & $13^{\circ} 30^{\prime}$ & $15^{\circ} 36^{\prime}$ & $13 / 10 / 05$ \\
\hline & Central River Area (CRA) & & & & \\
\hline 16 & Teneng Fara & IR_PSC & $13^{\circ} 37^{\prime}$ & $15^{\circ} 01^{\prime}$ & $23-24 / 08 / 06$ \\
\hline 17 & Wellingara Kejaw & IR_PSC \& IR_HC & $13^{\circ} 33^{\prime}$ & $14^{\circ} 55^{\prime}$ & $17 / 10 / 05 \& 16 / 11 / 05$ \\
\hline 17 & Wellingara Kejaw & IR_PSC \& IR_HC & $13^{\circ} 33^{\prime}$ & $14^{\circ} 55^{\prime}$ & $21-22 / 8 / 06$ \\
\hline 17 & Wellingara Kejaw & AS_PSC & $13^{\circ} 33^{\prime}$ & $14^{\circ} 55^{\prime}$ & $22 / 8 / 06$ \\
\hline 18 & Walikunda & IR_PSC & $13^{\circ} 34^{\prime}$ & $14^{\circ} 55^{\prime}$ & $22 / 8 / 06$ \\
\hline 19 & Saruja & IR_PSC \& IR_HC & $13^{\circ} 33^{\prime}$ & $14^{\circ} 54^{\prime}$ & $17 / 10 / 05 \& 17-18 / 11 / 05$ \\
\hline \multirow[t]{2}{*}{20} & Daru Wallof & IR_PSC & $13^{\circ} 60^{\prime}$ & $14^{\circ} 46^{\prime}$ & $8-9 / 09 / 06$ \\
\hline & Upper River Area (URA) & & & & \\
\hline 21 & Kabakamma & IR_HC & $13^{\circ} 18^{\prime}$ & $14^{\circ} 12^{\prime}$ & $18 / 10 / 05 \& 28 / 10 / 05$ \\
\hline 22 & Tinkinjo & IR_PSC \& IR_HC & $13^{\circ} 18^{\prime}$ & $14^{\circ} 10^{\prime}$ & $18 / 10 / 05 \& 28-10 / 05$ \\
\hline 22 & Tinkinjo & IR_PSC & $13^{\circ} 18^{\prime}$ & $14^{\circ} 10^{\prime}$ & $25 / 08 / 06$ \\
\hline 23 & Touba Tafsir & IR_PSC \& IR_HC & $13^{\circ} 17^{\prime}$ & $14^{\circ} 09^{\prime}$ & $28 / 10 / 05$ to $1 / 1 / 1 / 05$ \\
\hline 23 & Touba Tafsir & IR_PSC & $13^{\circ} 17^{\prime}$ & $14^{\circ} 09^{\prime}$ & $26-29 / 08 / 06$ \\
\hline 24 & Limbanbulu Yamadou & IR_PSC & $13^{\circ} 25^{\prime}$ & $14^{\circ} 07^{\prime}$ & $30 / 08 / 06$ to $1 / 09 / 06$ \\
\hline 25 & Kusunu & IR_PSC & $13^{\circ} 23^{\prime}$ & $13^{\circ} 55^{\prime}$ & $27 / 08 / 06$ \\
\hline \multirow[t]{2}{*}{26} & Kantel Kunda & IR_PSC & $13^{\circ} 24^{\prime}$ & $13^{\circ} 53^{\prime}$ & $27 / 08 / 06$ \\
\hline & Eastern Area, Tambacounda (TAM) & & & & \\
\hline 27 & Jingoreh Mafy & IR_PSC \& IR_HC & $13^{\circ} 46^{\prime}$ & $13^{\circ} 40^{\prime}$ & $21 / 10 / 2005 \& 24 / 10 / 05$ \\
\hline 27 & Jingoreh Mafy & IR_PSC & $13^{\circ} 46^{\prime}$ & $13^{\circ} 40^{\prime}$ & $10 / 09 / 06$ \\
\hline 28 & Jingoreh Babagaleh & IR_PSC & $13^{\circ} 41^{\prime}$ & $13^{\circ} 39^{\prime}$ & $21 / 10 / 05$ \\
\hline \multirow[t]{2}{*}{29} & Amdalaye pont & IR_PSC & $13^{\circ} 35^{\prime}$ & $13^{\circ} 33^{\prime}$ & $11 / 9 / 06 \&$ 16/9/06 \\
\hline & Eastern Area, Wassadou (WAS) & & & & \\
\hline 30 & Touba Badi & IR_PSC & $13^{\circ} 23^{\prime}$ & $13^{\circ} 23^{\prime}$ & $25 / 10 / 2005$ \\
\hline 31 & Wassadou & IR_PSC & $13^{\circ} 21^{\prime}$ & $13^{\circ} 21^{\prime}$ & $22-25 / 10 / 2005$ \\
\hline 31 & Wassadou & IR_PSC & $13^{\circ} 21^{\prime}$ & $13^{\circ} 21^{\prime}$ & $7 / 09 / 06 \& 15 / 09 / 06$ \\
\hline \multirow[t]{2}{*}{32} & Laboya & IR_PSC & $13^{\circ} 18^{\prime}$ & $13^{\circ} 21^{\prime}$ & $15 / 09 / 2006$ \\
\hline & Eastern Area, Kedougou (KED) & & & & \\
\hline 33 & Silling & IR_PSC & $12^{\circ} 32^{\prime}$ & $12^{\circ} 16^{\prime}$ & 14/9/06 \\
\hline 34 & Samecouta & $\mathrm{IR}_{-} \mathrm{PSC}$ & $12^{\circ} 36^{\prime}$ & $12^{\circ} 08^{\prime}$ & $26-27 / 10 / 05$ \\
\hline 34 & Samecouta & IR_PSC & $12^{\circ} 36^{\prime}$ & $12^{\circ} 08^{\prime}$ & $12-13 / 9 / 06$ \\
\hline 35 & Laminia & $\mathrm{IR}_{-} \mathrm{PSC}$ & $12^{\circ} 38^{\prime}$ & $12^{\circ} 07^{\prime}$ & $27 / 10 / 05$ \\
\hline
\end{tabular}




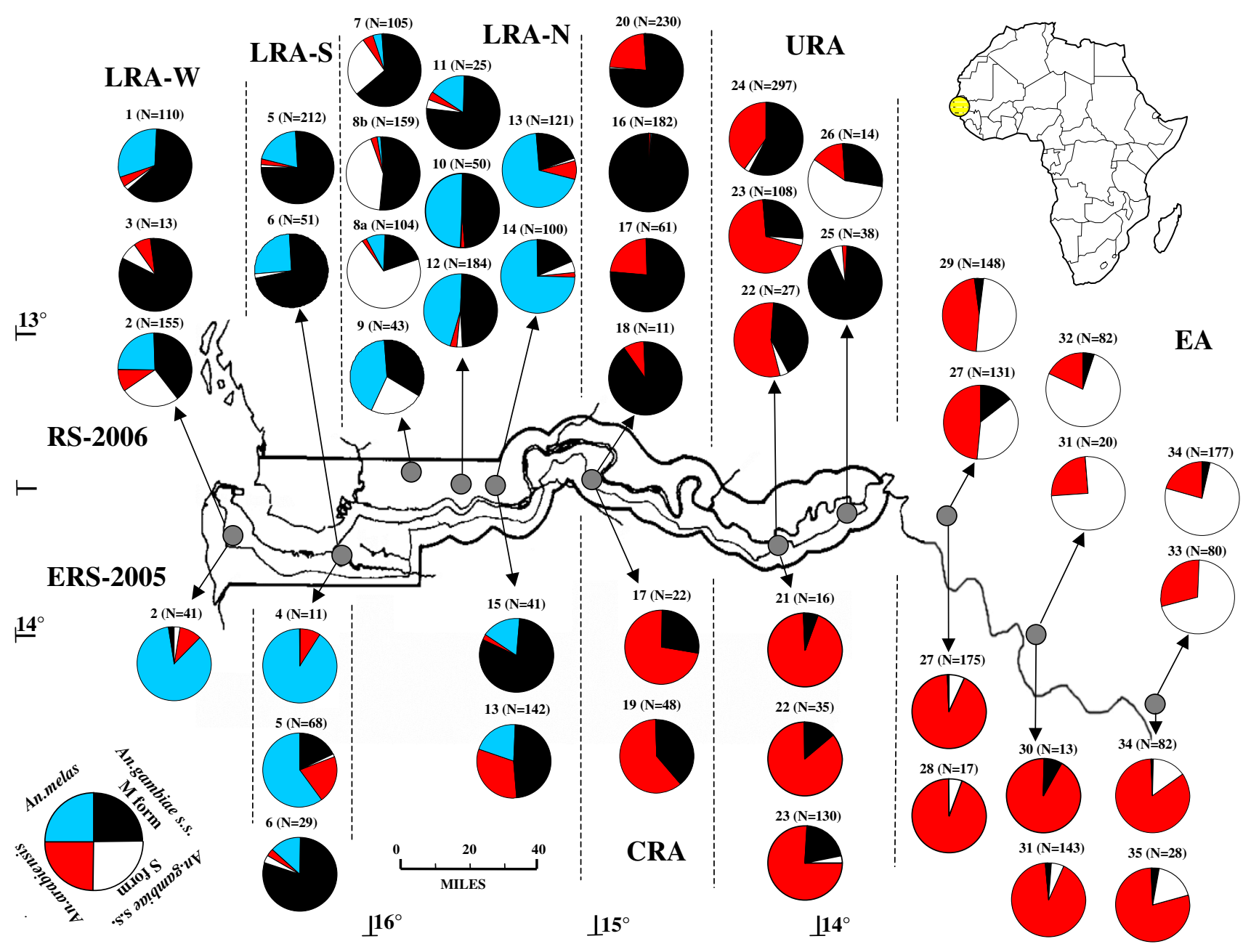

Figure I

Distribution of species and molecular forms of Anopheles gambiae complex in the study area. Numbers (and sample sizes) above pie-charts refer to samples, as listed in Table 2. Dashed lines indicate the boundaries of the arbitrarily defined areas and sub-areas (see text for details): Lower River Area, Western (LRA-W); Lower River Area, South Bank (LRA-S);

Lower River Area, North Bank (LRA-N); Central River Area (CRA); Upper River Area (URA); Eastern Area (EA). ERS-2005 = late rainy-early dry season 2005 (below); RS-2006 = rainy season 2006 (above).

patchily flooded swamps along its banks, and Yallal about $4 \mathrm{~km}$ away from the swamps; 3) three sites in Farafenni zone (Ballingho, Ker Madi and Kalataba, $900 \mathrm{mts}, 4.4 \mathrm{~km}$ and $5.3 \mathrm{~km}$ distant from the Gambia River, respectively) located near a large flooded swamp area and characterized by water-retaining, alluvial deposits.

\section{Central river area $(C R A)$}

In this area collections were carried out in four sites on the south bank of The River Gambia, approximately $180 \mathrm{~km}$ from the coast. The area is characterized by flat Sudan Savanna, where rice is traditionally cultivated all through the year thanks to extensive freshwater floodplains (ricefield landscape). Collections were carried out in Teneng Fara, a village located in area of open and flat farmland 5 $\mathrm{km}$ from the nearest rice field, and in three villages (Wellingara, Saruja and Walikunda) inside a large ricecultivated area within a $1 \mathrm{~km}$ range of each other, $13 \mathrm{~km}$ east of the first one. A single sample (RS-2006) was collected in the Senegalese village of Darou Wollof, $40 \mathrm{~km}$ north of the rice-cultivated area of Saruja.

Upper river area (URA)

The area lies more than $290 \mathrm{~km}$ from the coast, where the river banks are elevated and levees protect the poorly drained alluvial basins along the border of the river from flooding of the banks, which is confined to exceptionally heavy rainfall. This is the most arid area of The Gambia and mainly characterized by tree, shrub savanna and cultivated areas. Collections were carried out in: 1) Basse sub- 
area, which comprises two rural sites on the south bank (Tinkinjo and Touba Tafsir, at 2 and $3 \mathrm{~km}$ from a rice-field landscape, respectively) and a sub-urban site (Kabakama) within rice-fields; and 2) in the neighbouring, north bank village of Limbambulu, mainly characterized by cultivation and woods landscapes, and 3) in Kusunu sub-area, which comprises two sites in the south bank, characterized by swamp and cultivated landscapes near the river banks (Kantel Kunda and Kusunu).

\section{Eastern area (EA)}

The area extends from the eastern border of The Gambia to south-eastern Senegal, up to the foothills of the Futa Djalon highlands, near the border with Guinea. The flow of the river Gambia is less abundant than in the western areas and usually no flooding of the banks occurs. The area is mainly characterized by shrub and woodland savanna and large cultivated areas, which have largely replaced the natural forest ecosystem. Collections were carried out in three sub-areas, about $200 \mathrm{~km}$ from each other, as follows: 1) three sites in Tambacounda sub-area (TAM), within a southern Sudanese eco-climatic zone: Jingoreh Maffy and Jingoreh Babagaleh about $7 \mathrm{~km}$ from the Gambia river, and Amdalaye Pont, about $1.6 \mathrm{~km}$ east of them; 2) three sites in Wassadou sub-area (WAS), within Sudanese-Guinean eco-climatic zone close to Niokolokoba National Park: Wassadou, $0.5 \mathrm{~km}$ from the Gambia river and close to the Nieriko tributary; Touba Badi, about $9 \mathrm{~km}$ west from it, and Laboya, about $5 \mathrm{~km}$ south; 3 ) three sites in Kedougou sub-area (KED), within a Sudanese-Guinean zone, characterized by higher mean annual rainfall and more extended forested areas than the former two sub-areas: Samecouta, Laminia and Silling.

\section{Sampling techniques}

Collections of indoor daytime-resting mosquitoes were carried out mainly in human dwellings and, in few cases, in animal shelters. Prior to the start of the study, permission to collect live mosquitoes in private houses was sought from each village Alkalo (i.e head of the village) and short meetings were conducted to explain the purpose of the study. Verbal consent from householders was requested at every compound visited. Collections were carried out by three field collectors, using two main methods: i) by hand-operated aspirators [24] on domestic walls or inside bed-nets (IR_HC) from 7 to $12 \mathrm{AM}$, or ii) by pyrethroid ("BOP" ${ }^{\text {тм": }}$ Tetramethrin, d-Allethrin, Dichlorovos and Permethrin) spray collections (IR_PSC) from 12 AM to sunset. Few samples were collected in animal shelters either by hand-operated aspirators (AS_HC) or by pyrethroid spraying (AS_PSC). Blood from fed females was absorbed and dried on filter paper for bloodmeal source identification. Ovaries were dissected from half-gravid females for subsequent polytene chromosome analyses. Carcasses were kept in vials with Silicagel desiccant.

\section{Species/form identification and blood meal analysis}

Anophelines were identified using the morphological identification keys of Gillies \& de Meillon [25] and Gillies \& Coetzee [26]. Anopheles gambiae s.l. specimens were identified to species and molecular forms at the Fajara MRC laboratory (The Gambia), following the PCR-RFLP protocol by Fanello et al [27], using as template DNA extracted from the mosquito abdomen.

Whenever a putative $\mathrm{M} / \mathrm{S}$ hybrid was identified based on the rDNA-IGS-RFLP $\mathrm{M} / \mathrm{S}$ pattern, a second DNA extraction was performed at the University of Rome, from a single ovary in the case of the 2005 samples, and from one leg in the case of the 2006 samples. The resulting DNA templates were amplified using both PCR-RFLP protocols currently used for molecular form identification $[27,28]$. Filter paper spots were eluted in normal saline overnight and the human blood meal identification was carried out at the Farafenni MRC laboratory using an ELISA technique developed by Burkot et al [29].

Statistical analyses included Chi-square and Fisher Exact Probability (FET) tests, using VassarStat: Website for statistical computation [30], which was used also for computing $95 \%$ confidence intervals (CIs) of proportions.

\section{Results}

A total of 4,079 An. gambiae s.l. indoor-resting females were identified to the molecular form level $(1,041$ and 3,038 from 2005 and 2006 collections, respectively). Anopheles melas $(12.1 \%$ and $14.3 \%$ of ERS-2005 and RS2006 samples, respectively), An. arabiensis $(64.1 \%$ and 18.2\% of ERS-2005 and RS-2006, respectively), An. gambiae M-form (19.5\% and $46.1 \%$ of ERS-2005 and RS2006, respectively) and An. gambiae S-form (4.3\% and $21.3 \%$ of ERS-2005 and RS-2006, respectively) were found. Thirty-eight M/S hybrids were identified, which corresponds to a frequency of $1.6 \%$ of the An. gambiae s.s. collections in each of the two sampling years, while no hybrids among bonae species of the An. gambiae complex (e.g. An. gambiae/An. arabiensis, An. gambiae/An. melas, An. arabiensis/An. melas) were recorded.

\section{Anopheles gambiae species and forms distribution}

Spatial differences in the relative frequencies of species/ forms were found along the west to east transect during both sampling seasons. Table 2 and Figure 1 show the relative frequencies of species and molecular forms with respect to the overall sample collected in each site, not including hybrid $\mathrm{M} / \mathrm{S}$ specimens; HBI values are also shown. Table 3 and Figure 2 shows the relative frequencies of molecular forms with respect to the overall $A n$. 
gambiae s.s. sample collected in each site, including M/S specimens; Table 3 will be taken as a reference whenever the relative frequencies of $\mathrm{M}$ and $\mathrm{S}$-forms are described and/or compared later in the text. Results are presented with reference mainly to the most abundant samples and separately for each of the four previously defined geographic areas (see Material and Methods).

\section{Lower river area (LRA)}

Anopheles melas (ML), An. gambiae s.s. M-form (M) and Sform (S) and An. arabiensis (AR) were found to coexist in this area, between $16^{\circ} 45^{\prime} \mathrm{W}$ and $15^{\circ} 36^{\prime} \mathrm{W}$. Significant differences in the relative frequencies of the four taxa were observed among sampling sites and between sampling seasons and will be discussed within each of the 3 subareas, as follows:

In LRA-W, significant differences in the relative frequencies of the four taxa were observed between the two RS2006 sites with sample size $>100$ [ML vs AR vs M vs $S ; \chi^{2}$ $=33.3, \mathrm{df}=3, \mathrm{P}<0.001]$. This was due to a shift in the relative frequencies of $\mathrm{M}$ and S-forms $\left(\chi^{2}=32.7, \mathrm{df}=1, \mathrm{P}<\right.$ 0.001 ), with S-form showing lower frequency in the site characterized by the presence of rice fields (Kartong: Sform $=2.8 \%$ ), and a much higher frequency in the site characterized by other kind of cultivations and mangroves (Mandina Ba: S-form $=37.7 \%$ ). Moreover, in the latter village, An. melas predominated during ERS-2005, while M and S-form did in RS-2006; An. arabiensis frequency was $<10 \%$ in both seasons (ML vs AR vs M vs $S ; \chi^{2}=53.9, \mathrm{df}=$ $3, \mathrm{P}<0.001)$.

In LRA-S, An. melas and M-form were largely predominant over An. arabiensis and S-form. Significant differences in the species composition were observed between the two ERS-2005 samples with $\mathrm{N}>25$ (AR vs ML vs $\mathrm{M}+\mathrm{S} ; \chi^{2}=$ 34.9, $\mathrm{df}=2, \mathrm{P}<0.001$ ), but not in RS-2006. In the 2005 samples, An. melas was observed at higher frequencies in sites near mangroves and flooded swamps (Kemoto 90.9\%, CIs: 62.3-98.4; Tankular 60.3\%, CIs: 48.4-71) than in the site more distant from the Gambia River (Keneba: 13.8\%, CIs: 5.5-30.6). Seasonal differences in the relative frequencies of the four taxa were found between Tankular samples (ERS-2005 and RS-2006: AR vs $M L$ vs $M+S$; FET: $\mathrm{P}<0.001$ ), due to the predominance of An. melas and An. arabiensis at the end of the 2005 rainy season and of M-form during 2006 rainy season. In contrast, no seasonal differences were observed in Keneba. Mform greatly predominated over $S$ in all samples in both seasons (Keneba+Tankular ERS-2005+RS-2006, M-form = 97.5\%, CIs: 94.4-99).

In LRA-N, collections were carried out around Farafenni in ERS-2005 and in 2 other zones in a $40 \mathrm{~km}$ range from Farafenni westwards (i.e. Yallal and Njambakunda) in RS-
2006. In samples collected in the westernmost zone (i.e. Njabakunda), mainly characterized by free-draining sand laterite, An. melas and An. arabiensis were both observed at frequencies generally lower than $5 \%$, with the exception of An. melas in Sare Ilo Buya showing a frequency of $41.9 \%$. M and S molecular forms generally showed quite equal frequencies ( $\mathrm{M}$-form mean frequency $=61.2 \%$, CIs: 55.3-66.8), with the exception of the sample collected in Sara Samba Sowe during August, showing a significantly higher frequency of S-form [S-form $=80 \% ; M$ vs $S ; \chi^{2}=$ 42.1, $\mathrm{df}=1, \mathrm{P}<0.001]$. In samples collected in Yallal zone, M-form and An. melas were largely prevailing over Sform and An. arabiensis. No significant differences in the taxa composition were observed among the 3 sampling sites, although An. melas was found at relatively higher frequencies in sites closer to the river shores (Dai Mandinka: 50\%; Yallal: 46.7\%) than in the more distant site (Jajari: $16 \%$ ) (ML vs AR+M+S; $\left.\chi^{2}=9.21, \mathrm{df}=2, \mathrm{P}=0.01\right)$. M-form largely predominated over $\mathrm{S}$-form in all sites $(\mathrm{M}$-form > $95 \%$ ). In samples collected near the large swampy area within Farafenni zone, M-form and An. melas were largely prevailing over S-form and An. arabiensis in both sampling seasons. No differences in taxa composition were found between samples collected in RS-2006, while in ERS-2005 An. arabiensis was more abundant in Ker Madi (AR = $31.7 \%)$ than in Ballingho $(2.4 \%)$, which is adjacent to the river shore ( $M L$ vs $A R$ vs $M ; \chi^{2}=17.14, d f=2: P=0.0002$ ). In Ker Madi M-form and An. arabiensis frequencies were higher in ERS-2005 than in RS-2006, with An. melas showing an opposite trend (AR vs ML vs $M ; \chi^{2}=66.43, \mathrm{df}=2$ : $\mathrm{P}<0.001)$. S-form was observed only during RS-2006 at a relative frequency of $20.8 \%$ in Kalataba and $3.7 \%$ in Ker Madi.

\section{Central river area (CRA)}

Anopheles arabiensis and $\mathrm{M}$-form were virtually the only taxa found in this rice-field area $\left(15^{\circ} 01^{\prime} \mathrm{W}-14^{\circ} 54^{\prime} \mathrm{W}\right)$; a single $A n$. melas specimen was recorded in the village of Teneng Fara (RS-2006). In ERS-2005, An. arabiensis frequency was $>60 \%$. In RS-2006, M-form prevailed over $A n$. arabiensis, although significant differences were observed among samples collected within rice field irrigated areas (i.e. Wellingara: $M=77 \%$ ), in the proximity of the Gambia River (i.e. Walikunda: $M=91 \%$ ) and in farm land (i.e. Teneng Fara: $M=99 \%$ ) (Wellingara vs Walikunda vs Teneng Fara: AR vs M, FET: $\mathrm{P}<0.001)$. In Wellingara, the relative frequency of the two taxa was significantly different between the seasons (AR vs M; FET: P < 0.001), with An. arabiensis frequency ranging from $73 \%$ in ERS-2005 to $23 \%$ in RS-2006.

M-form (76,5\%) and An. arabiensis (22.6\%) were the most abundant taxa also in the Senegalese village of Darou Wollof, $40 \mathrm{~km}$ north of the Gambia River, and only few S-form specimens $(0.8 \%)$ were found. 


\begin{tabular}{|c|c|c|c|c|c|c|c|c|c|c|c|c|c|c|c|c|c|c|}
\hline \multirow[t]{2}{*}{$\begin{array}{l}\text { Site } \\
\text { code }\end{array}$} & \multirow[t]{2}{*}{ Village } & \multirow[t]{2}{*}{$\begin{array}{l}\text { TOT } \\
\text { (N) }\end{array}$} & \multicolumn{4}{|c|}{ An. arabiensis } & \multicolumn{4}{|c|}{ An. melas } & \multicolumn{4}{|c|}{ An. gambiae M-form } & \multicolumn{4}{|c|}{ An. gambiae S-form } \\
\hline & & & (\%) & Cls 95\% & HBI (N) & HBI (\%) & $(\%)$ & Cls & HBI (N) & HBI (\%) & (\%) & Cls & HBI (N) & HBI (\%) & (\%) & Cls & HBI (N) & HBI (\%) \\
\hline 1 & $\begin{array}{l}\text { LRA-W } \\
\text { Kartong }\end{array}$ & 110 & 4.55 & $1.9-10.21$ & n/a & $n / a$ & 30.91 & $23-40.1$ & 26 & 0.50 & 62.73 & 53.471 .2 & 56 & 0.66 & 1.82 & $0.5-6.4$ & n/a & $\mathrm{n} / \mathrm{a}$ \\
\hline 2 & Mandinaba & 41 & 9.76 & $3.8-22.5$ & n/a & n/a & 85.37 & $71.6-93.1$ & 35 & 0.69 & 2.44 & $0.4-12.6$ & $\mathrm{n} / \mathrm{a}$ & $n / a$ & 2.44 & $0.4-12.6$ & n/a & $n / a$ \\
\hline 2 & Mandinaba & 155 & 9.68 & $5.9-15.4$ & 11 & 0.45 & 24.52 & $\mid 8.4-31.8$ & 26 & 0.50 & 40.00 & $32.6-47.9$ & 33 & 0.52 & 25.81 & $19.6-33.2$ & 25 & 0.12 \\
\hline \multirow[t]{2}{*}{3} & Jiboro Kuta & 13 & 7.69 & $1.4-33.3$ & n/a & $\mathrm{n} / \mathrm{a}$ & 0.00 & $0-22.8$ & $n / a$ & n/a & 84.62 & $57.7-95.7$ & $\mathrm{n} / \mathrm{a}$ & $\mathrm{n} / \mathrm{a}$ & 7.69 & $1.4-33.3$ & n/a & $\mathrm{n} / \mathrm{a}$ \\
\hline & LRA-S & & & & & & & & & & & & & & & & & \\
\hline 4 & Kemoto & 11 & 9.09 & $1.6-37.7$ & n/a & n/a & 90.91 & $62.3-98.4$ & 10 & 0.80 & 0.00 & $0-25.9$ & n/a & n/a & 0.00 & $0-25.9$ & n/a & n/a \\
\hline 5 & Tankular & 68 & 20.59 & $12.7-31.6$ & 14 & 0.79 & 60.29 & 48.4-71.1 & 40 & 0.58 & 17.65 & $10.4-28.4$ & 12 & 0.75 & 1.47 & $0.3-7.9$ & n/a & n/a \\
\hline 5 & Tankular & 212 & 2.36 & $1-5.4$ & $\mathrm{n} / \mathrm{a}$ & $n / a$ & 20.28 & $15.4-26.2$ & 42 & 0.52 & 75.94 & $69.8-81.2$ & 158 & 0.45 & 1.42 & $0.5-4.1$ & n/a & n/a \\
\hline 6 & Keneba & 29 & 3.45 & $0.6-17.2$ & n/a & n/a & 13.79 & $5.5-30.6$ & n/a & n/a & 79.31 & $61.6-90.1$ & 19 & 0.47 & 3.45 & $0.6-17.2$ & n/a & n/a \\
\hline \multirow[t]{2}{*}{6} & Keneba & 51 & 0.00 & $0-7$ & n/a & n/a & 25.49 & $15.5-38.9$ & 13 & 0.46 & 72.55 & $59-82.9$ & 37 & 0.49 & 1.96 & $0.3-10.3$ & n/a & $n / a$ \\
\hline & LRA-N & & & & & & & & & & & & & & & & & \\
\hline 7 & Hamdalai & 105 & 4.76 & $2-10.7$ & n/a & n/a & 3.81 & $1.5-9.4$ & n/a & n/a & 64.76 & $55.2-73.2$ & 38 & 0.39 & 26.67 & $19.1-35.8$ & 19 & 0.26 \\
\hline $8 a$ & $\begin{array}{l}\text { are Samba } \\
\text { Sowe }\end{array}$ & 104 & 1.92 & $0.5-6.7$ & $n / a$ & $n / a$ & 8.65 & $4.6-15.6$ & $n / a$ & n/a & 19.23 & $12.8-27.8$ & 20 & 0.25 & 70.19 & $60.8-78.1$ & 73 & 0.23 \\
\hline $8 b$ & $\begin{array}{l}\text { Sare Samba } \\
\text { Sowe }\end{array}$ & 159 & 3.14 & $1.3-7.1$ & $\mathrm{n} / \mathrm{a}$ & n/a & 1.26 & $0.3-4.5$ & $n / a$ & n/a & 52.83 & $45.1-60.4$ & 82 & 0.44 & 42.77 & $35.3-50.5$ & 68 & 0.44 \\
\hline 8 & $\begin{array}{l}\text { Sare Samba } \\
\text { Sowe } 2006\end{array}$ & 263 & 2.66 & $1.3-5.4$ & n/a & $n / a$ & 4.18 & $2.3-7.3$ & n/a & n/a & 39.54 & $33.8-45.6$ & n/a & n/a & 53.61 & $47.6-59.5$ & n/a & n/a \\
\hline 9 & Sare Illo Buya & 43 & 0.00 & $0-8.2$ & n/a & n/a & 41.86 & $28.4-56.7$ & n/a & n/a & 34.88 & $22.4-49.8$ & $\mathrm{n} / \mathrm{a}$ & n/a & 23.26 & $13.2-37.7$ & n/a & n/a \\
\hline 10 & Dai Mandinka & 50 & 2.00 & $0.3-10.5$ & n/a & n/a & 50.00 & $36.6-63.4$ & 13 & 0.46 & 48.00 & $34.8-61.5$ & 15 & 0.40 & 0.00 & $0-7.1$ & n/a & n/a \\
\hline 11 & Jajari & 25 & 4.00 & $0.7-19.5$ & $\mathrm{n} / \mathrm{a}$ & $\mathrm{n} / \mathrm{a}$ & 16.00 & $6.4-34.6$ & $\mathrm{n} / \mathrm{a}$ & $n / a$ & 76.00 & $56.6-88.5$ & n/a & n/a & 4.00 & $0.7-19.5$ & n/a & n/a \\
\hline 12 & Yallal & 184 & 2.72 & $1.2-6.2$ & n/a & n/a & 46.74 & $39.7-53.9$ & 86 & 0.36 & 48.37 & $41.3-55.5$ & 89 & 0.21 & 2.17 & $0.8-5.4$ & n/a & n/a \\
\hline 13 & Ker Madi & 142 & 31.69 & $24.6-39.7$ & 45 & 0.53 & 20.42 & $14.6-27.8$ & 29 & 0.66 & 47.89 & $39.8-56$ & 68 & 0.76 & 0.00 & $0-2.6$ & n/a & n/a \\
\hline 13 & Ker Madi & 22 & 9.09 & $2.5-27.8$ & n/a & n/a & 68.18 & $47.3-83.6$ & n/a & n/a & 22.73 & $10.1-43.4$ & n/a & n/a & 0.00 & $0-149$ & n/a & n/a \\
\hline 13 & Ker Madi & 121 & 8.26 & $4.5-14.5$ & 10 & 0.80 & 69.42 & 60.76 .9 & 84 & 0.63 & 21.49 & $15.1-29.6$ & 26 & 0.77 & 0.83 & $0.1-4.5$ & n/a & n/a \\
\hline 14 & Kalataba & 100 & 2.00 & $0.5-7$ & n/a & n/a & 74.00 & $64.6-81.6$ & 74 & 0.04 & 19.00 & $12.5-27.8$ & 19 & 0.11 & 5.00 & $2.1-11.2$ & n/a & n/a \\
\hline 15 & Ballingho & 41 & 2.44 & $0.4-12.6$ & $\mathrm{n} / \mathrm{a}$ & $n / a$ & 17.07 & $8.5-31.3$ & n/a & n/a & 80.49 & $66-89.8$ & 33 & 0.24 & 0.00 & $0-8.6$ & n/a & n/a \\
\hline 15 & $\begin{array}{l}\text { Ballingho } \\
\text { CRA }\end{array}$ & 12 & 0.00 & $0-24.2$ & n/a & n/a & 58.33 & $31.9-80.7$ & n/a & n/a & 41.67 & $19.3-68$ & n/a & n/a & 0.00 & $0-24.2$ & n/a & $\mathrm{n} / \mathrm{a}$ \\
\hline 16 & Teneng Fara & 182 & 1.10 & $1.1-3$ & n/a & n/a & 0.55 & $0.1-3$ & n/a & n/a & 98.35 & 95.3-99.4 & 179 & 0.35 & 0.00 & $0-2.1$ & n/a & n/a \\
\hline 17 & $\begin{array}{l}\text { Wellingara } \\
\text { Kejaw }\end{array}$ & 22 & 72.73 & $51.8-86.8$ & 11 & 0.27 & 0.00 & $0-14.9$ & n/a & n/a & 27.27 & $13.1-48.5$ & n/a & n/a & 0.00 & $0-14.9$ & n/a & $n / a$ \\
\hline
\end{tabular}




\begin{tabular}{|c|c|c|c|c|c|c|c|c|c|c|c|c|c|c|c|c|c|c|}
\hline 17 & $\begin{array}{l}\text { Wellingara } \\
\text { Kejaw }\end{array}$ & 61 & 22.95 & $14.2-34.9$ & 14 & 0.43 & 0.00 & $0-5.9$ & $n / a$ & $n / a$ & 77.05 & $65.1-85.8$ & 47 & 0.19 & 0.00 & $0-5.9$ & $n / a$ & $n / a$ \\
\hline 17 & $\begin{array}{l}\text { Wellingara } \\
\text { Kejaw }\end{array}$ & 25 & 28.00 & $14.3-47.6$ & $n / a$ & $n / a$ & 0.00 & $0-13.3$ & n/a & $\mathrm{n} / \mathrm{a}$ & 72.00 & $52.4-85.7$ & n/a & n/a & 0.00 & $0-13.3$ & $n / a$ & $n / a$ \\
\hline 18 & Walikunda & 11 & 9.09 & $1.6-37.7$ & $n / a$ & $n / a$ & 0.00 & $0-25.8$ & $n / a$ & $\mathrm{n} / \mathrm{a}$ & 90.91 & $62.3-98.4$ & 10 & 0.10 & 0.00 & $0-25.8$ & $n / a$ & $n / a$ \\
\hline 19 & Saruja & 48 & 60.42 & $46.3-73$ & 23 & 0.65 & 0.00 & $0-0.7$ & n/a & $\mathrm{n} / \mathrm{a}$ & 39.58 & $27-53.7$ & 15 & 0.60 & 0.00 & $0-0.7$ & $n / a$ & $n / a$ \\
\hline 20 & $\begin{array}{l}\text { Daru wallof } \\
\text { URA }\end{array}$ & 230 & 22.61 & $17.7-28.4$ & 52 & 0.60 & 0.00 & $0-1.6$ & $n / a$ & $\mathrm{n} / \mathrm{a}$ & 76.52 & $70.6-81.5$ & 176 & 0.57 & 0.87 & $0.2-3.1$ & $n / a$ & $n / a$ \\
\hline 21 & Kabakamma & 16 & 93.75 & $71.7-98.9$ & 15 & 0.00 & 0.00 & $\mathrm{n} / \mathrm{c}$ & $n / a$ & $\mathrm{n} / \mathrm{a}$ & 6.25 & 1.1 & $\mathrm{n} / \mathrm{a}$ & $n / a$ & 0.00 & $0-19.4$ & $n / a$ & $n / a$ \\
\hline 22 & Tinkinjo & 35 & 85.71 & $70.6-93.7$ & 30 & 0.07 & 0.00 & $n / c$ & n/a & $\mathrm{n} / \mathrm{a}$ & 14.29 & $6.3-2.9$ & n/a & $n / a$ & 0.00 & $0-9.9$ & $\mathrm{n} / \mathrm{a}$ & $n / a$ \\
\hline 22 & Tinkinjo & 27 & 55.56 & $37.3-72.4$ & 15 & 0.13 & 0.00 & $\mathrm{n} / \mathrm{c}$ & n/a & $\mathrm{n} / \mathrm{a}$ & 40.74 & $24.5-59.3$ & 11 & 0.09 & 3.70 & $0.6-18.3$ & n/a & $n / a$ \\
\hline 23 & Touba Tafsir & 130 & 76.15 & $68.1-82.6$ & 99 & 0.06 & 0.00 & $n / c$ & n/a & $\mathrm{n} / \mathrm{a}$ & 20.77 & $14.7-28.5$ & 27 & 0.04 & 3.08 & $1.2-7.6$ & n/a & $n / a$ \\
\hline 23 & Touba Tafsir & 108 & 69.44 & $60.2-77.3$ & 75 & 0.63 & 0.00 & $\mathrm{n} / \mathrm{c}$ & n/a & $\mathrm{n} / \mathrm{a}$ & 27.78 & $20.2-36.9$ & 30 & 0.60 & 2.78 & $0.9-7.8$ & n/a & n/a \\
\hline 24 & $\begin{array}{l}\text { Limbanbulu } \\
\text { Yamadou }\end{array}$ & 297 & 40.40 & $35-46.1$ & 120 & 0.30 & 0.00 & $\mathrm{n} / \mathrm{c}$ & n/a & $\mathrm{n} / \mathrm{a}$ & 57.24 & $51.6-62.7$ & 170 & 0.49 & 2.36 & $1.1-4.8$ & n/a & $n / a$ \\
\hline 25 & Kusunu & 38 & 2.63 & $0.5-13.5$ & $n / a$ & $n / a$ & 0.00 & $\mathrm{n} / \mathrm{c}$ & n/a & $\mathrm{n} / \mathrm{a}$ & 92.11 & $79.2-97.3$ & 17 & 0.18 & 5.26 & $1.4-17.3$ & $n / a$ & $n / a$ \\
\hline 26 & $\begin{array}{l}\text { Kantel kunda } \\
\text { TAM }\end{array}$ & 14 & 14.29 & $4-39.9$ & $n / a$ & $n / a$ & 0.00 & $n / c$ & n/a & $\mathrm{n} / \mathrm{a}$ & 28.57 & 11.7 .54 .6 & n/a & $n / a$ & 57.14 & $32.6-78.6$ & n/a & $\mathrm{n} / \mathrm{a}$ \\
\hline 27 & Jingoreh Mafy & 175 & 92.57 & $87.7-95.6$ & 161 & 0.11 & 0.00 & $n / c$ & $\mathrm{n} / \mathrm{a}$ & $n / a$ & 0.57 & $0.1-3.2$ & n/a & $n / a$ & 6.86 & $4-11.6$ & 12 & 0.08 \\
\hline 27 & Jingoreh Mafy & 131 & 48.85 & $40.4-57.3$ & 26 & 0.35 & 0.00 & $\mathrm{n} / \mathrm{c}$ & $n / a$ & $n / a$ & 14.50 & $9.5-21.5$ & 11 & 0.64 & 36.64 & $28.9-45.2$ & 28 & 0.54 \\
\hline 28 & $\begin{array}{l}\text { Jingoreh } \\
\text { Babagaleh }\end{array}$ & 17 & 94.12 & 73-98.9 & 16 & 0.13 & 0.00 & $n / c$ & n/a & $n / a$ & 0.00 & $0-18.4$ & n/a & $n / a$ & 5.88 & I-27 & n/a & $n / a$ \\
\hline 29 & $\begin{array}{l}\text { Amdalaye pont } \\
\text { WAS }\end{array}$ & 148 & 46.62 & $38.8-54.6$ & 44 & 0.39 & 0.00 & $\mathrm{n} / \mathrm{c}$ & n/a & $\mathrm{n} / \mathrm{a}$ & 4.05 & $1.9-8.6$ & n/a & $n / a$ & 49.32 & $41.4-57.3$ & 50 & 0.34 \\
\hline 30 & Touba Badi & 13 & 92.31 & $66.7-98.6$ & 12 & 0.00 & 0.00 & $n / c$ & n/a & $\mathrm{n} / \mathrm{a}$ & 7.69 & $1.4-33.3$ & n/a & $n / a$ & 0.00 & $0-22.8$ & $\mathrm{n} / \mathrm{a}$ & $\mathrm{n} / \mathrm{a}$ \\
\hline 31 & Wassadou & 143 & 91.61 & $85.9-95.1$ & 131 & 0.14 & 0.00 & $n / c$ & n/a & $\mathrm{n} / \mathrm{a}$ & 2.80 & $1.1-7$ & n/a & $n / a$ & 5.59 & $2.9-10.6$ & n/a & $n / a$ \\
\hline 31 & Wassadou & 20 & 25.00 & $11.2-46.9$ & $n / a$ & $n / a$ & 0.00 & $n / c$ & n/a & $n / a$ & 0.00 & $0-16.1$ & n/a & $n / a$ & 75.00 & $53.1-88.8$ & 15 & 0.60 \\
\hline 32 & $\begin{array}{l}\text { Laboya } \\
\text { KED }\end{array}$ & 82 & 18.29 & $11.4-28$ & $n / a$ & $n / a$ & 0.00 & $n / c$ & n/a & $\mathrm{n} / \mathrm{a}$ & 4.88 & $1.9-11.9$ & n/a & $n / a$ & 76.83 & $66.6-84.6$ & 15 & 0.60 \\
\hline 33 & Silling & 80 & 30.00 & $21.1-40.7$ & 11 & 1.00 & 0.00 & $n / c$ & n/a & $\mathrm{n} / \mathrm{a}$ & 0.00 & $0-4.6$ & n/a & $n / a$ & 70.00 & $59.2-78.9$ & 36 & 0.86 \\
\hline 34 & Samecouta & 82 & 84.15 & 73.7-89.7 & 69 & 0.64 & 0.00 & $\mathrm{n} / \mathrm{c}$ & n/a & $n / a$ & 1.22 & $0.2-6.6$ & n/a & $n / a$ & 14.63 & $8.6-23.9$ & 12 & 0.58 \\
\hline 34 & Samecouta & 177 & 20.90 & $15.6-27.5$ & 30 & 0.63 & 0.00 & $n / c$ & n/a & $n / a$ & 3.95 & $1.9-7.9$ & n/a & $n / a$ & 75.14 & $68.3-80.9$ & 107 & 0.75 \\
\hline 35 & Laminia & 28 & 78.57 & $60.5-89.8$ & 22 & 0.50 & 0.00 & $\mathrm{n} / \mathrm{c}$ & $n / a$ & $n / a$ & 3.57 & $0.6-17.7$ & n/a & $n / a$ & 17.86 & $7.9-35$ & n/a & n/a \\
\hline
\end{tabular}


Table 3: Distribution of Anopheles gambiae s.s. molecular forms in the study area.

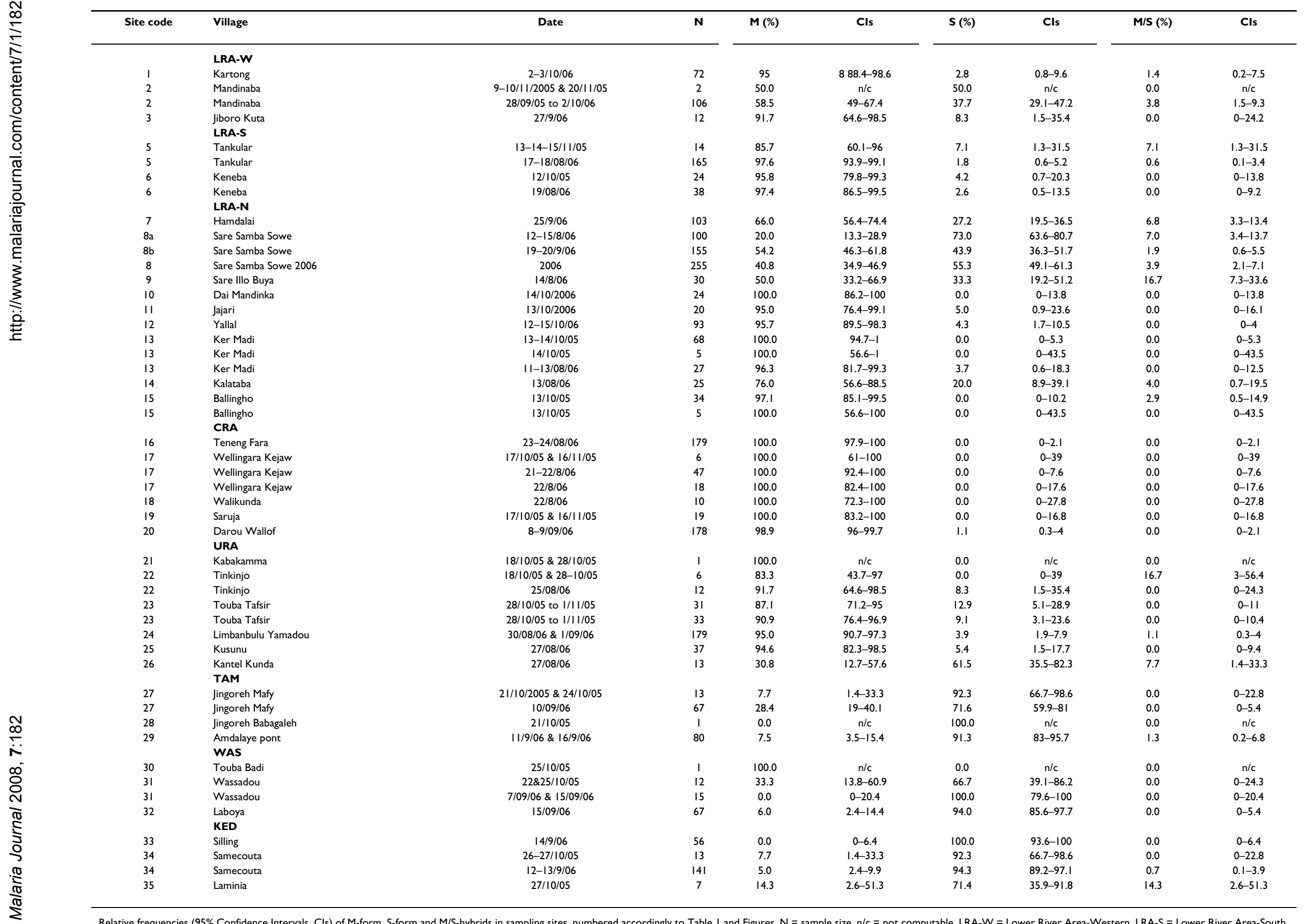




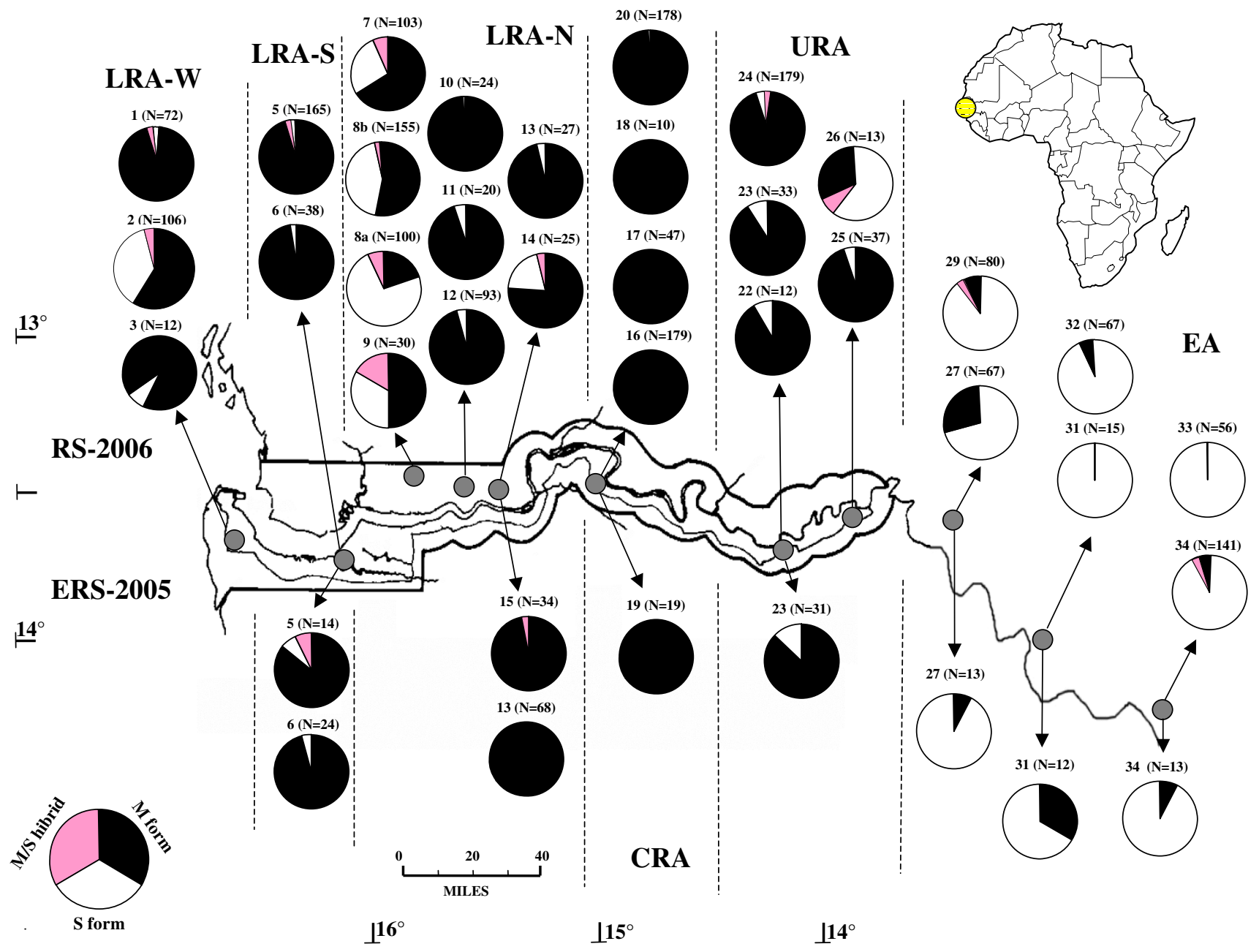

Figure 2

Distribution of molecular forms of Anopheles gambiae s.s. in the study area. Numbers (and sample sizes) above piecharts refer to samples with $\mathrm{N}>10$, as listed in Table 3. Dashed lines indicate the boundaries of the arbitrarily defined areas and sub-areas (see text for details): Lower River Area, Western (LRA-W); Lower River Area, South Bank (LRA-S); Lower River Area, North Bank (LRA-N); Central River Area (CRA); Upper River Area (URA); Eastern Area (EA). ERS-2005 = late rainyearly dry season 2005 (below); RS-2006 = rainy season 2006 (above).

Upper river area (URA)

In the two sampling sub-areas in the eastern part of The Gambia (i.e. Basse and Kusunu) ranging from $14^{\circ} 12^{\prime} \mathrm{W}$ to $13^{\circ} 53^{\prime} \mathrm{W}$, An. arabiensis was the most abundant taxon, particularly at the end of the 2005 rainy season (ERS2005: 76.4\%, CIs: 70.2-81.7; RS-2006: 50.8\%, CIs: 46.954.8 ) and was always found in sympatry with $\mathrm{M}$-form (ERS-2005: 21.2\%, CIs: 16.2-27.2; RS-2006: 45.1\%, CIs: 41.2-49.1). S-form was observed in most samples at frequencies around 5\%, with the exception of the Kantel Kunda sample (RS-2006), where it was the most abundant taxon observed (57.1\%).
In Basse sub-area, no significant variation in the taxa composition was observed among most sites, with An. arabiensis prevailing even in the rainy season. In Limbabulu, An. arabiensis and $\mathrm{M}$-form showed balanced frequencies and S-form was $2.4 \%$. In Kusunu sub-area, An. arabiensis had a frequency $<15 \%$.

The M-form largely predominated over S-form in Basse sub-area in both seasons $(>80 \%)$, as well as in the RS2006 in Limbambulu sample (95\%). Conversely, in the easternmost sub-area of Kusunu, M-form frequency varied from $94.6 \%$ in Kusunu to $30.8 \%$ in Kantel Kunda (M vs S: FET: $\mathrm{P}<0.001)$. 


\section{Eastern area (EA)}

In the three sampling sub-areas in eastern Senegal, situated from $13^{\circ} 40^{\prime} \mathrm{W}$ to $12^{\circ} 07^{\prime} \mathrm{W}$ and mainly characterized by shrub and wooded savanna, S-form and An. arabiensis were the most abundant taxa. M-form was observed in sympatry with the other two taxa at frequencies generally lower than $5 \%$. The relative frequencies of the three taxa did not vary among sampling sites within each sub-area in the two sampling seasons. Relative frequencies of S-form were significantly higher in RS-2006 than in ERS-2005 [AR vs M vs S; Jingoreh Maffy (TAM): $\chi^{2}=75.5, \mathrm{df}=2, \mathrm{P}<$ 0.001; Wassadou: FET, P < 0.001; Samecouta (KED): AR vs $M$ vs S, FET: $P<0.001]$. Throughout the area, S-form always largely prevailed over $\mathrm{M}$-form (mean $\mathrm{S}$ frequency $>$ 90\%, CIs: 87-92.4), although spatial variations in their relative frequencies were observed in Tambacouda subarea.

\section{Anopheles gambiae s.s. M/S hybrids}

Thirty-eight of the 40 specimens (95\%) initially providing a hybrid M/S rDNA-IGS-RFLP pattern were confirmed as $\mathrm{M} / \mathrm{S}$ hybrids (see Materials and Methods). These were recorded along the whole west to east transect (Table 3), as follows: $4 / 252$ in 4 of the 17 indoor-resting samples collected in ERS-2005 and 34/2084 in 11 out of 29 samples collected in RS-2006, corresponding to about $1.6 \%$ of An. gambiae s.s. specimens in both sampling seasons. In the case of Tankular (LRA-S), M/S hybrids were found in both sampling seasons and in the sample from Sare Samba Sowe (LRA-N) they were found in collections carried out in two different months of the same season (i.e. August and September 2006). M/S hybrids were found in all 7 samples with $\mathrm{N}=100$ where both forms were recorded, while they were not found in the sample collected in Teneng-Fara (CRA, $\mathrm{N}=179$ ) where $\mathrm{M}$-form only was found.

\section{Blood-meal analyses}

The HBI values of An. gambiae s.l. blood-fed samples $(\mathrm{N}=$ 3,392) with $\mathrm{N}>10$ specimens are reported in Table 2. Large variations were observed along the transect within species and forms, as follows.

Anopheles melas mean HBI values were 65\% (CIs: 55.873 ) in the 4 samples collected in ERS-2005; except for the Kalataba sample which showed a HBI of $4 \%$, the mean HBI values of RS-2006 samples was 50\% (CIs: 44-55.4). No significant seasonal variations were observed between samples collected in Tankular and Ker Madi. A HBI value of $43 \%$ was observed in one small An. melas sample collected in animal shelters in $\operatorname{Ker}$ Madi $(\mathrm{N}=14)$ in ERS2005, which is not significantly different from those observed in samples simultaneously collected inside human dwellings.
Anopheles arabiensis mean HBI values ranged between $43 \%$ and $80 \%$ in samples collected in the western part of the transect (i.e. from LRA-W to CRA) during both sampling seasons. In samples from the eastern part of the transect (i.e. URA, Tambacounda and Wassadou sub-areas), a mean HBI value of $10 \%$ (CIs: 7.5-13) was observed in ERS-2005, while HBI values ranged from $13 \%$ to $63 \%$ in RS-2006. In samples from Kedogou sub-area, a mean HBI of 60\% (CIs: 50.2-69.9) and 73.2\% (CIs: 58.1-84.3) were observed in ERS-2005 and RS-2006, respectively. HBI values were generally lower in samples collected during ERS2005 compared to those collected in the same sampling sites in RS-2006.

A very high variability in $H B I$ values was observed in $A n$. gambiae M-form samples along the whole transect. While no significant seasonal variations were observed between samples collected in Tankular (LRS) and Ker Madi (LRN), a significantly lower HBI value was found in Touba Tafsir (URA) in ERS-2005 (4\%) than in RS-2006 (60\%) $\left(\chi^{2}=\right.$ 17.8, $\mathrm{df}=1, \mathrm{P}<0.001)$.

During RS-2006, S-form HBI values ranged from $29.7 \%$ west of CRA to $64.1 \%$ eastwards $\left(\chi^{2}=49.1\right.$, df $=1, \mathrm{P}<$ $0.0001)$. In Jingoreh Mafy, where samples were collected during both seasons, HBI value were lower in ERS-2005 (8\%) than in RS-2006 (54\%) (FET, P = 0.0001).

Significant differences were generally neither observed between An. melas and M-form in western localities (e.g. Mandina Ba, LRA-W, Tankular, LRA-S, Ker Madi, LRA-N), nor between An. arabiensis and M-form in CRA (e.g. Welingara) and URA (e.g. Touba Tafsir and Tinkinjo), nor between An. arabiensis and S-form in Eastern area (e.g. Tambacouda and Kedougou sub-areas). In the few sympatric $M$ and $S$ samples compared, the two forms showed a significantly different HBI only in Mandina Ba samples ( $52 \%$ vs $12 \%$, respectively, $\chi^{2}=16.6, \mathrm{df}=1, \mathrm{P}<0.001$ ).

\section{Discussion}

\section{Spatial and temporal distribution}

The results obtained provide a picture of the temporal and spatial distribution of An. gambiae taxa along the west to east transect sampled. The results presented are based on samples of female mosquitoes collected while resting inside human dwellings. Thus, it is likely that the observed relative frequencies of the species/forms in the samples are biased by differences in their relative endophilic/exophilic and/or anthropophilic/zoophilic behaviours. In particular, on the basis of the information available on the biology of the taxa in the area, it can be anticipated that the frequency of An. melas, and possibly, to a lesser extent of An. arabiensis, are probably underestimated [2]. Nevertheless, a general trend in the distribution of the An. gambiae taxa, showing evidence of 
bionomic divergences among them, can be inferred, as discussed below with reference to each taxon separately.

Anopheles melas was found in all Gambian sampling sites characterized by the presence of nearby mangrove and brackish water, up to ca. $180 \mathrm{~km}$ inland from the coast, as already reported by Bryan et al. [2]. The finding of a single specimen in CRA (RS-2006) probably reflects the limit of penetration of the species eastwards. Anopheles melas showed a reversed temporal population dynamics as compared to the sympatric fresh-water taxa, being generally present at higher relative frequencies at the end of the rainy season than during the rainy season, consistent with previous data from Bryan et al [2] and Bogh et al [3]. Unexpectedly, relative frequencies of An. melas were higher in Farafenni sub-area than in western sites during RS-2006, while the opposite was observed in ERS-2005. However, it should be stressed that immediate saltwater concentration strongly affects An. melas ability to colonize brackishwater larval habitats and to compete with An. gambiae s.s. larvae [3], thus causing non-uniform population dynamics due to short/medium term fluctuations and interactions between tides and rainfalls, which may have affected our results.

Anopheles arabiensis was observed along the whole transect in sympatry mainly with $\mathrm{M}$-form and An. melas westwards of the easternmost Gambia-Senegal border, and with S-form eastwards. It generally showed low relative frequencies (about 7\%, in average) and no seasonal variations in the western part of the transect. From CRA eastwards, An. arabiensis mostly showed frequencies $<50 \%$ during the rainy season, consistent with data from Bryan et al [2] for The Gambia, while from the end of the rainy season onwards it was the generally prevailing taxon $(>60 \%)$. The latter observation, reported for the first time from this area, was expected to some extent due to the well known better adaptation of An. arabiensis to relatively dry biotopes [31,32]. In Basse sub-area (URA) An. arabiensis was found at frequencies $>50 \%$ also in RS-2006, as previously reported by Hogg et al [33], while it showed marked seasonal variations in CRA, as reported by Lindsay et al [5]. Interestingly, in contrast to CRA, Basse sub-area is characterized by rare natural flooding of the river banks and by breeding sites mainly represented by marshes and by rice fields dependent on rain rather than by flooding from the river. This further confirms the observations by Bogh et al [3], who reported higher densities of An. arabiensis larvae in rain-dependent rice fields than in other breeding habitats.

Anopheles gambiae s.s. molecular forms showed a very distinct pattern of distribution, with $\mathrm{M}$-form and S-form largely prevailing in western and eastern sampling sites, respectively, as follows.
The M-form was present in all sampling areas during both sampling seasons and was the most frequent taxon found during the rainy season in the western and in the central parts of the transect (i.e. in The Gambia), which are largely characterized by alluvial flooded areas. It was: i) found in sympatry mainly with An. melas in the coastal areas, where the $\mathrm{M}$-form generally increases its relative frequencies in the rainy season; ii) the only molecular form present in all sampling sites in CRA, where rice is traditionally cultivated throughout the year, thanks to extensive freshwater irrigation from the Gambia River; iii) found in sympatry mainly with An. arabiensis from CRA up to approximately the border between The Gambia and Senegal (i.e. URA), where the $\mathrm{M}$-form increased its relative frequencies in the rainy season; iv) found sporadically and at low frequencies in eastern Senegal, where it was sympatric with An. arabiensis, which predominated at the end of the rainy season, and with S-form, which predominated in the rainy season.

The S-form was mainly found in rural areas in eastern Senegal, where the environmental impact of the Gambia River is much less profound than in The Gambia and agricultural activities are mainly rain-dependent. It was: i) generally found at relatively low frequency and in sympatry with M-form and An. melas in LRA, where its abundance seems to be largely dependent on rainfall; ii) absent in all sampling sites in CRA; iii) found sporadically and generally at low frequencies in URA; iv) always largely predominating over M-form in EA, where it showed higher relative frequencies in the rainy season and a temporal population dynamics opposite to that of the sympatric An. arabiensis populations.

With reference to the relative abundance of $M$ and $S$ molecular forms only (Figure 2), the prevalence of one form over the other was observed in most sites, independent of the season of collection, as observed also in many other west African regions [7]: in 22 out of 31 sites of sympatry with sample size $>10$, the frequency of the dominant form was $>85 \%$, with $M$-form predominating in sites near flooded areas in LRA, CRA and URA, and S-form predominating in EA, which is characterized by more humid conditions and degraded forest. In contrast, $M$ and $S$ showed more equal frequencies during RS-2006 in: i) the coastal site of Mandina $\mathrm{Ba}$, where rain-dependent cultivations are largely practiced, ii) drier areas in LRA-N approximately 5 $\mathrm{km}$ north from the flooded area bordering the Gambia River (i.e Njabakunda sub-area) and in iii) some sites of eastern URA-western EA, which seems to be a transitional area, where $\mathrm{M}$-form gives way to S-form eastwards.

\section{Anopheles gambiae s.s. M/S hybrids}

Overall, 38 specimens showing an M/S hybrid rDNA-IGSRFLP-pattern were identified along the whole west to east 
transect (see Table 3 and Figure 2). The technical precautions taken during the processing of these samples allow to rule out the possibility that these patterns are due to contamination between carcasses or DNAs. This is further confirmed by the absence in the overall sample of other hybrid patterns (e.g. S-form/An. arabiensis, M-form/An. melas, An. arabiensis/An. melas, etc).

It is important to note that it is not possible to rule out the hypothesis that some of the specimens characterized by rDNA-IGS-RFLP $\mathrm{M} / \mathrm{S}$ pattern represent the progeny of back-crosses involving the $\mathrm{M} / \mathrm{S}$ hybrids, rather than the F1 progeny of an "inter-form" cross. Moreover, it has to be stressed that IGS mutations recognised by RFLP could be not fully linked with genes responsible for assortative mating between $M$ and $S$ and that recombination in the IGS region might have led to a breakdown of the $M$ and $S$ diagnostic in this geographical area. As a consequence, the finding of $\mathrm{M} / \mathrm{S}$ patterns may not necessarily reflect current gene flow between the two molecular forms. The availability of a novel molecular approach to identify $\mathrm{M}$ and $\mathrm{S}$ may help clarifying these issues [34].

The results obtained apparently show that the reproductive barriers between the two molecular forms are not as strong in the study area as they are in other areas (see below). M/S hybrids were found at frequencies ranging from to $0.6 \%$ to $7 \%$, in all seven samples with $N=100$ each, where both molecular forms were recorded (in 5 of these samples more than one single $\mathrm{M} / \mathrm{S}$ specimen was found; moreover, in the sample from Sare Illo Buya (LRA$\mathrm{N}$ ), five out of only 30 specimens analysed were $\mathrm{M} / \mathrm{S}$ hybrids). On the other hand, no $\mathrm{M} / \mathrm{S}$ specimens were reported in this study from the CRA, where $M$ was the only molecular form recorded.

The putative (i.e. based on the presumption that all $\mathrm{M} / \mathrm{S}$ specimens found represent the F1 progeny of an "interform" cross) frequency of hybridization found along the Gambia River is apparently much higher than that reported so far for other areas. In fact, very strong assortative mating has been consistently shown between molecular forms and, although a frequency of $1.2 \%$ cross mating was observed in a village in Mali [35], only six M/ $S$ hybrids have been reported out of almost 7,000 An. gambiae s.s. individuals from north-west Africa and none from west-central Africa ( $>10,000)$ [7]; each M/S hybrid was found in a different sampling site, as follows: three in localities from Mali (M/S = 0.3\%; $\mathrm{N}=329)$, Burkina Faso $(\mathrm{M} / \mathrm{S}=0.3 \% ; \mathrm{N}=327)$ and Benin $(\mathrm{M} / \mathrm{S}=1.0 \% ; \mathrm{N}=96)$ where $\mathrm{M}$ and $\mathrm{S}$ were sympatric; the remaining three in samples from The Gambia (M/S $=4.8 \% ; \mathrm{N}=21)$, Guinea $(\mathrm{M} / \mathrm{S}=1.5 \% ; \mathrm{N}=67)$ and Ivory Coast $(\mathrm{M} / \mathrm{S}=1.1 \% ; \mathrm{N}=$ 90) where only one molecular form was recorded, although the presence of the other form could not be excluded. Interestingly, the single $\mathrm{M} / \mathrm{S}$ hybrid recorded in The Gambia in September 2003 was found in Walikunda (CRA), where $\mathrm{M}$ was the only molecular form found also at that time.

\section{Feeding behaviour}

Large variations in HBI values were observed along the transect within each taxon. Anopheles melas generally showed HBI values between $35 \%$ and $69 \%$ with no significant seasonal variations. However, it should be stressed that HBI values obtained in this survey refer to females collected while resting inside human dwellings, and cannot be assumed to be a precise estimation of the feeding preferences of each taxon, particularly in the case of exophagic, exophilic and zoophilic species, such as An. melas [2].

Anopheles arabiensis showed an even greater range of $\mathrm{HBI}$ values, with significant spatial variations: in fact, during both sampling seasons, HBI values were significantly lower in URA and Tambacounda and Wassadou sub-areas than in the coastal sites up to CRA and in Kedougou subarea. Although the relative abundance of different hosts was not recorded, these variations could be explained by the opportunistic feeding habits of the species, resulting in its host choice being determined by the relative, local abundance of alternative hosts to humans [36]. In fact, data from Farafenni area showed significantly lower HBI values in the presence of cattle hosts than in their absence in samples collected during the 1997 dry season [37].

Large spatial and temporal variations were observed in each of the An. gambiae molecular forms, with HBI values ranging from $4 \%$ to $77 \%$ for $\mathrm{M}$, and from $8 \%$ to $86 \%$ for $\mathrm{S}$. These values are not consistent with those observed in other regions of West Africa for An. gambiae s.s., which is generally a very anthropophilic species and therefore very weakly affected by the abundance of hosts alternative to humans $[38,39]$. The HBI values found in Ker Madi (77\%) and Mandina $\mathrm{Ba}(49 \%)$ in RS-2006 were close to those observed in the same localities by Bryan et al [2] (i.e. 73\% and $46 \%$, respectively), who hypothesized that these HBI values were due to a different availability of animal hosts in the villages. On the other hand, a HBI of around 55\% was recently observed in Farafenni area, regardless of the presence/absence of cattle [37]. It is possible that the apparent low anthropophagy of $\mathrm{M}$ and $\mathrm{S}$ molecular forms in the study area, which markedly contrasts with the wellknow feeding behaviour of An. gambiae throughout Africa, could be the result of the extensive domestic use of anti-mosquito measures (e.g. coils, bed-nets, etc) [40], which may have shifted the biting activities towards other domestic animal hosts, such as horses and donkey, which are frequent in the area $[37,41]$. 
Overall, larger variations in HBI values were observed among sites than among taxa. In western localities, Mform and An. melas showed similar HBI values, contrary to previous observation by Bryan et al. (1987), who found HBI values generally higher for An. gambiae than for An. melas. In central localities (CRA and URA), M-form and An. arabiensis generally showed similar HBI values, confirming previous observations on An. gambiae s.s. and An. arabiensis in The Gambia [37] and Senegal [4,42,43]. Large temporal and spatial variations, especially in samples from URA, were observed in HBI values within Mform and An. arabiensis and, interestingly, the HBI values of the two taxa varied in a parallel way, showing very low values $(<10 \%)$ in samples collected in URA during ERS2005. S-form and An. arabiensis populations from EA showed similar HBI values and large temporal and spatial variations: lower values were observed in ERS-2005 $(\sim 10 \%)$ than in RS-2006 ( $40 \%)$ in Tambacounda area and significantly higher values were observed in both seasons in samples collected from Kedougou sub-area (60$75 \%$ ), consistent with previous observation on An. gambiae and An. arabiensis from Senegal $[43,44]$. Our results, although preliminary, do not show evidence of differences in HBI between $M$ and $S$ indoor resting females, confirming previous preliminary observations from Cameroon [14] and Angola [15].

\section{Conclusion}

Overall, the pattern of distribution of the two An. gambiae molecular forms in the study area suggests a better adaptation of $\mathrm{M}$-form to areas characterized by water-retaining alluvial deposits along the Gambia River, with marshy vegetation and rice cultivation, rich in breeding-sites dependent on fresh water infiltration from the river banks and on irrigated/flooded areas. On the other hand, S-form seems to be better adapted to free-draining soil covered with open woodland savannah or farmland, rich in raindependent breeding sites, abundant during the rainy season. This apparent bionomic divergence between the two molecular forms is consistent with the proposed hypothesis of a higher ability of M-form to colonize semi-permanent larval habitats, whereas S-form would be more adapted to rain-dependent, temporary breeding sites. On this subject, further studies are in progress by our groups to understand whether the extensive rice field-rich area in CRA, colonized exclusively by M-form (prevailing in the rainy season) and An. arabiensis (prevailing in the dry season), may represent an ecological barrier for the S-form, affecting the genetic composition of the western and eastern S-populations in the study area.

Finally, the relatively high frequency of $\mathrm{M} / \mathrm{S}$ hybrids found in the $M$ and S sympatric areas of the whole study transect, regardless of the season, suggests that gene-flow between molecular forms may be greater in the study area than in other parts of West Africa. This observation encourages further studies on the genetic differentiation between the molecular forms and on the potential restriction to gene-flow in the western extreme of An. gambiae s.s. distribution range.

\section{Competing interests}

The authors declare that they have no competing interests.

\section{Authors' contributions}

$\mathrm{BC}, \mathrm{MJ}, \mathrm{DN}, \mathrm{DJC}, \mathrm{ID}$ and LK organized and carried out the field collections. DN, MA and BC performed the molecular identification of the samples. MJ performed the bloodmeal analyses. BC, DN, MJ, VP, DJC and AdT participated in the analysis and interpretation of data. DJC and AdT supervised the whole project. BC, VP and AdT wrote the manuscript, with assistance from their collaborating authors. All authors read and approved the final manuscript.

\section{Additional material}

\begin{abstract}
Additional file 1
Monthly rainfall in study area. Monthly rainfall $(\mathrm{mm})$ in: $L R A-W=$ Lower River Area Western, LRA-S = Lower River Area South Bank, LRA$N=$ Lower River Area North Bank, CRA = Central River Area, URA = Upper River Area, TAM = Tambacounda, KED = Kedougou, during October-2005 (red line), August-2006 (blue line) and September-2006 (green line). Data from local meteorological stations. Click here for file [http://www.biomedcentral.com/content/supplementary/14752875-7-182-S1.ppt]
\end{abstract}

\section{Additional file 2}

Landscape analysis for Gambian villages where collections were carried out. Relative frequencies of the seven landscape classes within a 1$\mathrm{km}$ radius from the centre of the village. Rice field (yellow), Cultivation (red), Woods (green), Mangrove (light-blue), Grass land (grey), Swamp (dark-blue), Populated Area (black). Numbers above pie-charts refer to samples as listed in Table 1. Dashed lines indicate the boundaries of the arbitrarily defined areas and sub-areas. $L R A-W=$ Lower River Area-Western, LRA-S = Lower River Area-South Bank, LRA-N = Lower River Area-North Bank, CRA = Central River Area, URA = Upper River Area.

Click here for file

[http://www.biomedcentral.com/content/supplementary/14752875-7-182-S2.ppt]

\section{Acknowledgements}

Field collections and laboratory analysis in The Gambia was supported by the Medical Research Council of the UK, with helpful facilitation from the Gambian National Malaria Control Programme. We thank Abdoulie Jallow and Mbye Njie for their help with entomological collections, and Demba Sanneh for laboratory support with species and molecular form typing. BC was supported by PhD programme in "Pasteurian Sciences" from University of Rome "La Sapienza" (Italy). BC field activities was partly supported by grant Al42 I 2 I from the National Institutes of Health. DN was supported by 
EDCTP fellowship award. We thank Prof. Mario Coluzzi for advice and support.

\section{References}

I. Bryan JH, Di Deco MA, Petrarca V, Coluzzi M: Inversion polymorphism and incipient speciation in Anopheles gambiae s.s. in Gambia, West Africa. Genetica 1982, 59:167-176.

2. Bryan JH, Petrarca V, Di Deco MA, Coluzzi M: Adult behaviour of members of the Anopheles gambiae complex in the Gambia with special reference to An. melas and its chromosomal variants. Parassitologia 1987, 29:221-249.

3. Bogh C, Clarke SE, Jawara M, Thomas CJ, Lindsay SW: Localized breeding of the Anopheles gambiae complex (Diptera: Culicidae) along the River Gambia, West Africa. Bull Entomol Res 2003, 93:279-287.

4. Fontenille D, Lochouarn L, Diatta M, Sokhna C, Dia I, Diagne N, Lemasson JJ, Ba K, Tall A, Rogier C, Trape JF: Four years' entomological study of the transmission of seasonal malaria in Senegal and the bionomics of Anopheles gambiae and $A$. arabiensis. Trans R Soc Trop Med Hyg 1997, 91 :647-652.

5. Lindsay SW, Wilkins HA, Zieler HA, Daly RJ, Petrarca V, Byass P: Ability of Anopheles gambiae mosquitoes to transmit malaria during the dry and wet seasons in an area of irrigated rice cultivation in The Gambia. J Trop Med Hyg I991, 94:313-324.

6. della Torre A, Fanello C, Akobeto M, Dossou-yovo J, Favia G, Petrarca V, Coluzzi M: Molecular evidence of incipient speciation within Anopheles gambiae s.s. in West Africa. Insect Mol Biol 2001, 10:9-18.

7. della Torre $A, T u Z$, Petrarca $V$ : On the distribution and genetic differentiation of Anopheles gambiae s.s. molecular forms. Insect Biochem Mol Biol 2005, 35:755-769.

8. Turner TL, Hahn MW, Nuzhdin SV: Genomic islands of speciation in Anopheles gambiae. PLoS Biol 2005, 3:e285.

9. della Torre A, Costantini C, Besansky NJ, Caccone A, Petrarca V, Powell JR, Coluzzi M: Speciation within A nopheles gambiae the glass is half full. Science 2002, 298: I I $5-1$ I 7 .

10. Costantini C, Pombi M, Palladino C, Santolamazza S, della Torre A, Petrarca V, Coluzzi M, Sagnon N'F: Bionomic differences among sympatric Anopheles arabiensis and An. gambiae molecular forms $M$ and $S$ in an arid savanna area of Burkina Faso. Suppl Am J Trop Med Hyg Program and Abstracts of the 5 / st Annual Meeting of ASTMH. Denver, CO 2002, 67:350-35I.

II. Costantini C, Pombi M, Pelladino C, della Torre A, Petrarca V, Sagnon N'F: Habitat distribution of Anopheles gambiae molecular forms in breeding sites of an arid savanna village in Burkina Faso. Suppl Am J Trop Med Hyg Program and Abstracts of the 52nd Annual Meeting of ASTMH. Philadelphia, PA 2003, 69:210.

12. Diabate A, Dabire RK, Kim EH, Dalton R, Millogo N, Baldet T, Simard F, Gimnig JE, Hawley WA, Lehmann T: Larval development of the molecular forms of Anopheles gambiae (Diptera: Culicidae) in different habitats: a transplantation experiment. J Med Entomol 2005, 42:548-553.

13. Diabate A, Dabire RK, Heidenberger K, Crawford J, Lamp WO, Culler LE, Lehmann T: Evidence for divergent selection between the molecular forms of Anopheles gambiae: role of predation. BMC Evol Biol 2008, 8:5.

14. Wondji C, Frederic S, Petrarca V, Etang J, Santolamazza F, della Torre A, Fontenille D: Species and populations of the Anopheles gambiae complex in Cameroon with special emphasis on chromosomal and molecular forms of Anopheles gambiae s.s. J Med Entomol 2005, 42:998-1005.

15. Calzetta M, Santolamazza F, Carrara GC, Cani PJ, Fortes F, Di Deco MA, della Torre A, Petrarca V: Distribution and chromosomal characterization of the Anopheles gambiae complex in Angola. Am J Trop Med Hyg 2008, 78: 169-175.

16. Toure YT, Petrarca V, Coluzzi M: Comparative estimate of the rates of infection with sporozoites and filaria in various forms of the Anopheles gambiae complex in a village in Mali. Ann Ist Super Sanita 1986, 22:215-217.

17. Touré YT, Petrarca V, Traore SF, Coulibaly A, Maiga HM, Sankare O, Sow M, Di Deco MA, Coluzzi M: The distribution and inversion polymorphism of chromosomally recognized taxa of the Anopheles gambiae complex in Mali, West Africa. Parassitologia |998, 40:477-5 I I.
18. Santolamazza F, Calzetta M, Etang J, Barrese E, Dia I, Caccone A, Donnelly MJ, Petrarca V, Simard F, Pinto J, della Torre A: Distribution of knock-down resistance mutations in Anopheles gambiae molecular forms in west and west-central Africa. Malar J 2008, 7:74.

19. Trolldalen JM: On the fringe: a systems approach to the evolution of the environment and agricultural production in The Gambia, West Africa, 1948-1983. Volume 10. University of Oslo, Norway; 1991.

20. Thomson M, Connor S, Bennett S, D'Alessandro U, Milligan P, Aikins $M$, Langerock P, Jawara M, Greenwood B: Geographical perspectives on bednet use and malaria transmission in The Gambia, West Africa. Soc Sci Med 1996, 43:101-112.

21. Dia I, Lochouarn L, Boccolini D, Costantini C, Fontenille D: Spatial and temporal variations of the chromosomal inversion polymorphism of Anopheles funestus in Senegal. Parasite 2000, 7:179-184.

22. Beck LR, Rodriguez MH, Dister SW, Rodriguez AD, Rejmankova $E$, Ulloa A, Meza RA, Roberts DR, Paris JF, Spanner MA, Washino RA, Hacker C, Legters LJ: Remote sensing as a landscape epidemiologic tool to identify villages at high risk for malaria transmission. Am J Trop Med Hyg 1994, 5 I:27 I-280.

23. Beck LR, Rodriguez MH, Dister SW, Rodriguez AD, Washino RK, Roberts DR, Spanner MA: Assessment of a remote sensingbased model for predicting malaria transmission risk in villages of Chiapas, Mexico. Am J Trop Med Hyg 1997, 56:99- 106.

24. Coluzzi M, Petrarca V: Aspirator with paper cup for collecting mosquitoes and other insects. Mosq News 1973, 33:249-250.

25. Gillies MT, De Meillon B: The Anophelinae of Africa south of the Sahara (Ethiopian Zoogeographical Region). Publ S Afr Inst Med Res 1968, 54:1-343.

26. Gillies MT, Coetzee M: A supplement to the Anophelinae of Africa south of the Sahara (Afrotropical Region). Publ S Afr Inst Med Res 1987, 55:1-|43.

27. Fanello C, Santolamazza F, della Torre A: Simultaneous identification of species and molecular forms of the Anopheles gambiae complex by PCR-RFLP. Med Vet Entomol 2002, I 6:461-464.

28. Santolamazza F, della Torre A, Caccone A: Short report: A new polymerase chain reaction-restriction fragment length polymorphism method to identify Anopheles arabiensis from An. gambiae and its two molecular forms from degraded DNA templates or museum samples. Am J Trop Med Hyg 2004, 70:604-606.

29. Burkot TR, Goodman WG, DeFoliart GR: Identification of mosquito blood meals by enzyme-linked immunosorbent assay. Am J Trop Med Hyg 198I, 30: I 336-I34I.

30. [http://faculty.vassar.edu/lowry/VassarStats.html].

31. Petrarca V, Nugud AD, Ahmed MA, Haridi AM, Di Deco MA, Coluzzi $M$ : Cytogenetics of the Anopheles gambiae complex in Sudan, with special reference to An. arabiensis: relationships with East and West African populations. Med Vet Entomol 2000 , 14:149-164.

32. Oyewole IO, Awolola TS, Ibidapo CA, Oduola AO, Okwa OO, Obansa JA: Behaviour and population dynamics of the major anopheline vectors in a malaria endemic area in southern Nigeria. J Vector Borne Dis 2007, 44:56-64.

33. Hogg JC, Thomson MC, Hurd H: Comparative fecundity and associated factors for two sibling species of the Anopheles gambiae complex occurring sympatrically in The Gambia. Med Vet Entomol 1996, 10:385-391.

34. Santolamazza F, Mancini E, Simard F, Qi Y, Tu Z, della Torre A: Insertion polymorphisms of SINE200 retrotransposons within speciation islands of Anopheles gambiae molecular forms. Malar J 2008, 7:163.

35. Tripet F, Toure YT, Taylor CE, Norris DE, Dolo G, Lanzaro GC: DNA analysis of transferred sperm reveals significant levels of gene flow between molecular forms of Anopheles gambiae. Mol Ecol 200I, I 0: I725-1732.

36. Costantini C, Gibson G, Sagnon N, Della Torre A, Brady J, Coluzzi M: Mosquito responses to carbon dioxide in a west African Sudan savanna village. Med Vet Entomol 1996, 10:220-227.

37. Bogh C, Clarke SE, Pinder M, Sanyang F, Lindsay SW: Effect of passive zooprophylaxis on malaria transmission in The Gambia. J Med Entomol 2001, 38:822-828.

38. White GB: Anopheles gambiae complex and disease transmission in Africa. Trans R Soc Trop Med Hyg 1974, 68:278-30I. 
39. Bryan JH: Anopheles gambiae and A. melas at Brefet, The Gambia, and their role in malaria transmission. Ann Trop Med Parasitol 1983, 77: I-12. I

40. Wiseman V, McElroy B, Conteh L, Stevens W: Malaria prevention in The Gambia: patterns of expenditure and determinants of demand at the household level. Trop Med Int Health 2006, I I:4|9-43|.

4I. Kirby MJ, Green C, Milligan PM, Sismanidis C, Jasseh M, Conway DJ, Lindsay SW: Risk factors for house-entry by malaria vectors in a rural town and satellite villages in The Gambia. Malar J 2008, 7:2.

42. Diatta M, Spiegel A, Lochouarn L, Fontenille D: Similar feeding preferences of Anopheles gambiae and A. arabiensis in Senegal. Trans R Soc Trop Med Hyg 1998, 92:270-272.

43. Lemasson J], Fontenille D, Lochouarn L, Dia I, Simard F, Ba K, Diop A, Diatta M, Molez JF: Comparison of behavior and vector efficiency of Anopheles gambiae and An. arabiensis (Diptera:Culicidae) in Barkedji, a Sahelian area of Senegal. J Med Entomol 1997, 34:396-403.

44. Fontenille D, Lochouarn L, Diagne N, Sokhna C, Lemasson JJ, Diatta M, Konate L, Faye F, Rogier C, Trape JF: High annual and seasonal variations in malaria transmission by anophelines and vector species composition in Dielmo, a holoendemic area in Senegal. Am J Trop Med Hyg 1997, 56:247-253.

Publish with Bio Med Central and every scientist can read your work free of charge

"BioMed Central will be the most significant development for disseminating the results of biomedical research in our lifetime. "

Sir Paul Nurse, Cancer Research UK

Your research papers will be:

- available free of charge to the entire biomedical community

- peer reviewed and published immediately upon acceptance

- cited in PubMed and archived on PubMed Central

- yours - you keep the copyright

Submit your manuscript here:

http://www.biomedcentral.com/info/publishing_adv.asp
BioMedcentral 